\title{
Inorganic nanomaterials in the aquatic environment: behavior, toxicity, and interaction with environmental elements
}

\author{
Iwona Krzyżewska1 ${ }^{1}$, Joanna Kyzioł-Komosińska ${ }^{1,2 *}$, Czesława Rosik-Dulewska ${ }^{1,2}$, \\ Justyna Czupioł', Patrycja Antoszczyszyn-Szpicka ${ }^{3}$ \\ ${ }^{1}$ Institute of Environmental Engineering \\ Polish Academy of Sciences, Poland \\ ${ }^{2}$ Department of Land Protection, Opole University, Poland \\ ${ }^{3}$ Central Mining Institute, Poland
}

*Corresponding author's e-mail: joanna.kyziol-komosinska@ipis.zabrze.pl

\begin{abstract}
Keywords: nanomaterials, nanosilver, nanocopper, aquatic environmental, toxicity, pollution.
\end{abstract}
\begin{abstract}
The aim of this paper is to present characteristics, toxicity and environmental behavior of nanoparticles (NPs) (silver, copper, gold, zinc oxide, titanium dioxide, iron oxide) that most frequently occur in consumer products. In addition, NPs are addressed as the new aquatic environmental pollutant of the $21^{\text {st }}$ century. NPs are adsorbed onto particles in the aquatic systems (clay minerals, fulvic and humic acids), or they can adsorb environmental pollutants (heavy metal ions, organic compounds). Nanosilver (nAg) is released from consumer products into the aquatic environment. It can threaten aquatic organisms with high toxicity. Interestingly, copper nanoparticles (Cu-NPs) demonstrate higher toxicity to bacteria and aquatic microorganisms than those of nanosilver $\mathrm{nAg}$. Their small size and reactivity can cause penetration into the tissues and interfere with the metabolic systems of living organisms and bacterial biogeochemical cycles. The behavior of NPs is not fully recognized. Nevertheless, it is known that NPs can agglomerate, bind with ions (chlorides, sulphates, phosphates) or organic compounds. They can also be bound or immobilized by slurry. The NPs behavior depends on process conditions, i.e. $\mathrm{pH}$, ionic strength, temperature and presence of other chemical compounds. It is unknown how NPs behave in the aquatic environment. Therefore, the research on this problem should be carried out under different process conditions. As for the toxicity, it is important to understand where the differences in the research results come from. As NPs have an impact on not only aquatic organisms but also human health and life, it is necessary to recognize their toxic doses and know standards/regulations that determine the permissible concentrations of NPs in the environment.
\end{abstract}

\section{Introduction}

In recent years, dynamic developments in technology have fostered new ways of creating nanoscale materials (particles that have dimensions $<100 \mathrm{~nm})$. The branch of science that deals with nanomaterials (NMs) is termed nanotechnology (Cademartini and Ozin 2011). By 2020, the annual production of NMs will have reached 58,000 $\mathrm{Mg}$ (Jo et al. 2012). In recent years, the development of NMs has generated a new industry and has provided new commercial products. However, the increased use of NMs has raised anxiety because of their prospective environmental and health impacts on living organisms (Zhu et al. 2009, Fouqueray et al. 2012). The fear is caused by a lack of adequate knowledge about the environmental behavior and safety of nanoparticles (NPs) and an absence of insight on their mechanisms of action in organisms. The production and use of NMs results in releases that may produce various effects on exposed aquatic organisms. Although not extensive, some studies have been performed that address the toxic effects, mechanism of action in living organisms, bioaccumulation, and bioavailability of NMs (Fouqueray et al. 2012, Zhu et al. 2010, Fan et al. 2012).

Different forms of inorganic NMs include nanometals (silver, copper, platinum, and gold), nano-oxides of metals (copper oxide, zinc oxide, iron oxides, and aluminium oxide, titanium dioxide), and quantum dots (CdS, CdSe, and InAs) (Table 1). Moreover materials supported nanometals and nano-oxides of metals are designed (Ayanda et al, 2015, Moreno et al 2014).

Because of their properties, NMs are used in nearly every industry, such as electronics, computers, cosmetics (including sunscreens), medicine and pharmaceuticals, dentistry, textiles, catalysts, anticorrosive and antibacterial coatings, metallic tools and parts, polymer composites and sorbents (Hoyt and Mason 2008, Bina et al. 2012). In addition, there are geogenic sources of NMs. These include volcanic eruptions, forest fires, and weathering of rocks. Most NMs present in the environment are the result of 
human activities, such as industrial production (Farre et al. 2011). In contrast to macroscale particles of the same substance, NMs are defined by their having the following characteristics (Cademartini and Ozin 2011, Kelsall et al. 2009, Kurzydłowski et al. 2011):

1. a higher specific surface area and a larger surface to volume ratio;

2. a lower melting point;

3. a decreasing ionization potential with a decreasing NPs size;

4. a higher chemical reactivity from unusual molecular arrangements;

5. a cracking resistance and a higher mechanical strength, while retaining elasticity, flexibility, and ability to reversed formation;

6. a magnetic property; and

7. a photocatalytic, photoconductive, and photoemissive capability.

NMs are synthesized by two methods (Cademartini and Ozin 2011):

- Bottom-up-involving construction from the ground up, atom by atom. The building blocks are molecules, atoms, or NMs components. The properties of the synthesized NMs are controlled by preselecting the size of the particles.

- Top-down-involving the fragmentation of larger molecules to reduce size and to redistribute macroscopic materials or particles into smaller pieces. This is the simplest method and is known as microstructural engineering.

There are also biological methods for synthesizing NPs from metals such as gold and iron oxides. The mechanism by which NPs are biosynthesized is not well understood, although metabolic processes and the presence of enzymes and proteins in the intracellular environment of microorganisms are involved (Gericke and Pinches 2006, Revati and Pandey 2011).

The objectives of this paper are to characterize the present status of selected inorganic NMs (viz., silver, gold, copper, titanium dioxide, zinc, and iron oxide NPs) and to address their environmental release from commercial and market applications, as well as their fate in the aquatic environment. In addition, we describe the interaction of these NMs with elements of the natural environment. We also try to show how toxic concentrations of them affect aquatic microorganisms.

\section{Presence of nanomaterials in the environment}

Various NMs products are on the market. These include NMs made from silver, copper, gold, zinc and iron oxides, and titanium dioxide (Table 2).

Table 1. Classes of inorganic engineered nanomaterials (Peralta-Videa et al. 2011)

\begin{tabular}{|c|c|c|}
\hline METALS & METAL OXIDES & QUANTUM DOTS \\
\hline $\begin{array}{c}\text { Silver } \\
(\mathrm{nAg})\end{array}$ & $\begin{array}{c}\text { Titanium dioxide } \\
\left(\mathrm{nTiO}_{2}\right)\end{array}$ & $\begin{array}{c}\text { Cadmium sulfide } \\
(\mathrm{CdS})\end{array}$ \\
\hline $\begin{array}{c}\text { Gold } \\
(\mathrm{nAu})\end{array}$ & $\begin{array}{c}\text { Iron oxides } \\
\left(\mathrm{nFe}_{\mathrm{x}} \mathrm{O}_{\mathrm{y}}\right)\end{array}$ & $\begin{array}{c}\text { Cadmium selenide } \\
(\mathrm{CdSe})\end{array}$ \\
\hline $\begin{array}{c}\text { Copper } \\
(\mathrm{nCu})\end{array}$ & $\begin{array}{c}\text { Zinc oxide } \\
(\mathrm{nZnO})\end{array}$ & $\begin{array}{c}\text { Indium arsenide } \\
(\text { InAs })\end{array}$ \\
\hline
\end{tabular}

Table 2. Applications of nanomaterials

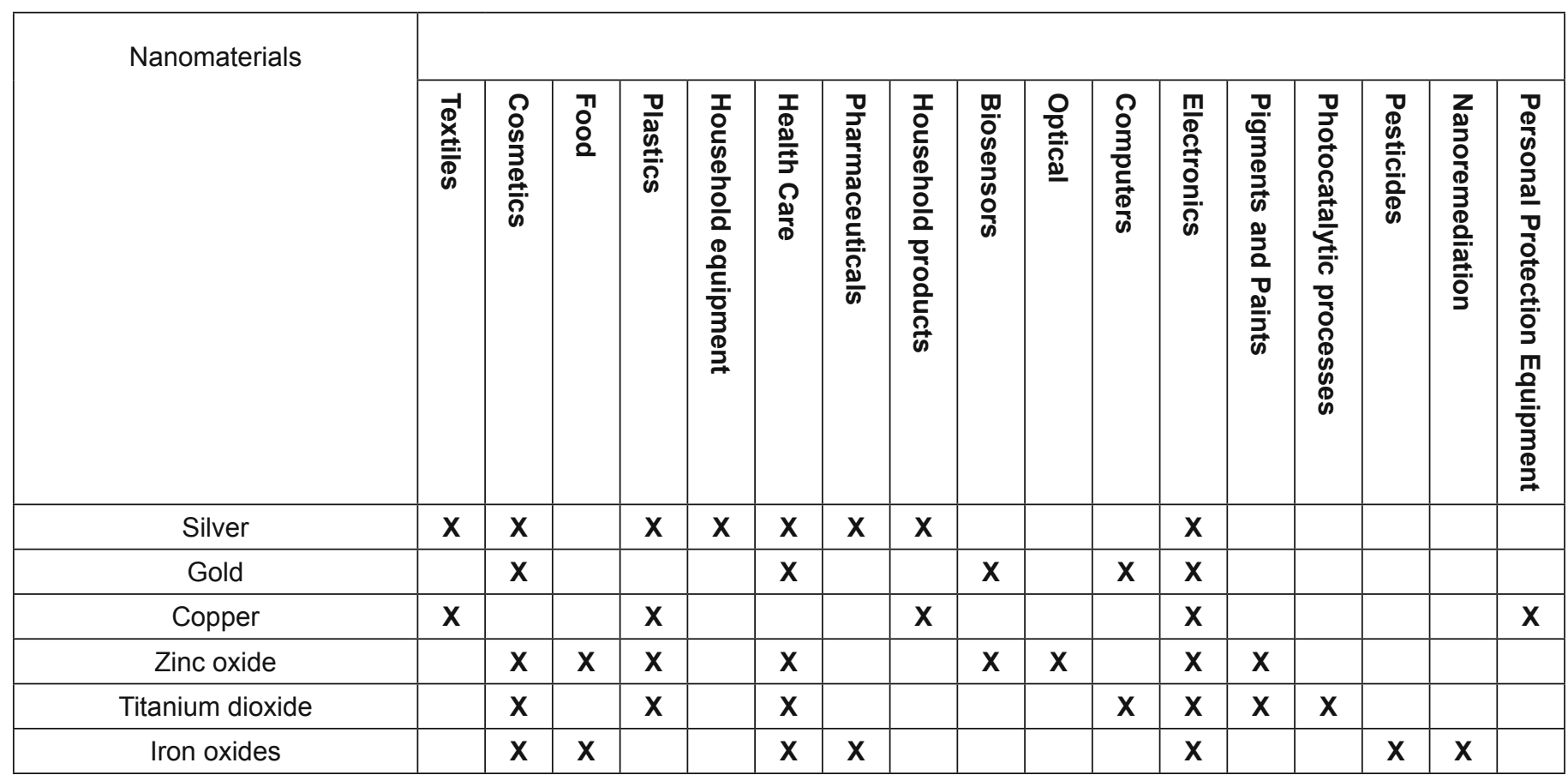


Nanosilver (nAg) is applied as a component in cosmetics (creams, shampoos, deodorants, and body lotions), textiles (socks, shirts, trousers, and term active underwear), bags and boxes that contain food, household products (cleaning fluids, detergents, and aerosols), and household appliances (washing machines and dishwashers). Dental practices and beauty salons offer treatments that employ the antibacterial and antifungal properties of nAg. Moreover, a growing number of commercially available textiles are fabricated with metal NPs in the structures; such NPs offer biocidal properties and prevent excessive sweating. The content of $\mathrm{nAg}$ in socks, pants, and shirts depends on the type of NPs used, their method of production, their shape and size and their physical and chemical properties (Makles 2005, Bystrzejewska-Piotrowska et al. 2009, Menget et al. 2007, Blaser et al. 2008). Textiles available on the market contain an average of 31 to $2,600 \mathrm{ppm}$ of nAg in T-shirts (Walser et al. 2011), 0.9 to 1,358 ppm nAg in socks (Benn and Wasterhoff 2008), and 88 to $170 \mathrm{ppm} \mathrm{nAg}$ in socks made from cotton (Zhang et al. 2009a).

Nanogold $(\mathrm{nAu})$ particles are used in biosensors and medical articles. nAu particles exhibit very good thermal and optical properties, whereas their large surface area in storage media allows the retention of large amounts of data in a small space (Tedesco et al. 2010, Balasubramanian et al. 2010, Zhang et al. 2003, Carlos et al. 2012, Kunzmann et al. 2011).

Because of its low price, nanocopper $(\mathrm{nCu})$ particles are used in household products, duvets and pillows, personal protective equipment, and sanitary equipment.

Zinc oxide nanoparticles ( $\mathrm{ZnO}-\mathrm{NPs}$ ) are used in electronic and optical applications as sensors, semiconductors, and lasers (Aruoja et al. 2009, Petosa et al. 2012, Jiang et al. 2010, 2012, Ramani et al. 2012). ZnO nanostructures are widely applied in cosmetics, and serve as pigments, UV filters in sunscreens, and dermatological products (Aruoja et al. 2009, Zhou and Keller 2010, Jiang et al. 2012a). ZnO-NPs are also applied as components of pigments, certain plastic material, and food additives (Zhou and Keller 2010, Petosa et al. 2012, Wilson et al. 2007).

Titanium dioxide nanoparticles $\left(\mathrm{TiO}_{2}-\mathrm{NPs}\right)$ are applied in paints, sunscreens, and solar cells and are used in photocatalytic water treatment processes (Lin et al. 2012). The $\mathrm{TiO}_{2}$-NPs are present in the structure of packaging and plastic containers that are used to package food. These materials are economical and safe for the environment and do not interact negatively with food particles. NMs present in packaging migrate to the environment throughout their life cycle. It is not easy to predict how they respond after the release and what the consequences of their interactions are (Iavicoli et al. 2012). The purpose of adding them to the structure of bags is to preserve food quality and improve storage safety, food taste, food structure and texture. They are also added for protection against pathogenic bacteria (Cockburn et al. 2012). $\mathrm{TiO}_{2}$-NPs are applied as components in self-cleaning and antifogging surfaces, in detergents, in sterilizing agents, and to photocatalytically purify air and water (Babaizadeh and Hassan 2013). The $\mathrm{TiO}_{2}-\mathrm{NPs}$ are also applied in electrochromic windows that have antireflection properties (they absorb UV radiation) (Ding et al. 2000, Kamisli and Turan 2005, Fujishima et al. 2000, Tazawa et al. 2004). On by which $\mathrm{TiO}_{2}-\mathrm{NPs}$ achieves "self-cleaning" is by degrading and mineralizing organic pollutants under the influence of solar energy (weak UV radiation) and oxygen. This self-cleaning of $\mathrm{TiO}_{2}-\mathrm{NPs}$ is also associated with the photo-inductive hydrophilic properties that the moiety possesses (Mills et al. 2003, Fujishima and Zhang 2006).

The magnetic properties of iron oxide nanoparticles are utilized in electrotechnics as ferrofluid and magnetic storage media. In nanoremediation processes that mediate wastewater treatment, zerovalent iron particles $\left(\mathrm{nFe}^{0}\right)$ are used for removing dyes, chloro-organic solvents, polychlorinated biphenyls, organochlorine pesticides, and toxic heavy metals. Nanoparticles of iron oxides are utilized in the cosmetic industry as sunscreens. Iron oxide nanoparticles are also used in pharmaceutical science (for magnetic separation of chemical compounds), DNA detection, magnetic drug targeting, magnetic resonance imaging (contrast agents), and as a component in dietary supplements and nutrients (Schwegmann et al. 2010, Brullot et al. 2012, Nor et al. 2012, Kadar et al. 2010, Carlos et al. 2012, Adeleye et al. 2013, Chen et al. 2011, Pawlett et al. 2013, Mohmood et al. 2013). Manufacturers of products containing NMs are convinced that they have positive effects on human health and improve the appearance of skin, reduce sweating, and prevent inflammation caused by microorganisms.

\section{Release of nanoparticles into the environment}

Currently, no standards have been established for permissible levels of NPs in the environment. Moreover, their presence in different environmental matrices is not systematically monitored, although their release may negatively affect living organisms. Metal nanoparticles present in fabrics are released to surface waters and perhaps to groundwater as a consequence of discharge to wastewater after textiles are laundered. Thereafter, they may also reach soils and the organisms that reside therein. Sewage treatment systems do not fully remove nanoparticles from wastewater streams, mainly because of their small particle size (Gottschalk et al. 2011). Water quality regulations only limit elemental metal concentrations, such as copper, silver, zinc, or titanium in surface, ground, and drinking waters (the values are given in Table 3 ) and do not yet address the nanoforms of these elements. Zinc, copper, and silver are the most important water pollutants because of their potential toxicity to living organisms. Metal nanoparticle analogues of these macroscale toxic metals could possess similar toxic properties.

The wide and growing use of NMs has increased the release of NPs to aquatic systems (Fig. 1). The main sources of metal NPs that pollute aquatic systems derive from residential households. NPs are released from various products and materials, such as textiles, cosmetics, food packaging and medicines. NPs released from textiles reach sewage systems, and eventually, wastewater treatment plants. A portion of wastewater is retained in septic tanks, which may pollute groundwater. Other sources of pollution from NMs are releases of industrial wastes from production sites, hospitals, and medical centres or clinics. The sources of NMs released to the terrestrial environment that may reach surface or groundwater include packaging materials for consumer cosmetics, food or medical waste, and pharmaceuticals that contain NMs (Maynard 2006, Fairbairn et al. 2011, Brar et al. 2010). 
Because of their small size and strong reactivity, NPs may adsorb onto sludge and form agglomerates with organic matter. NPs may also penetrate cell membranes of organisms and bind cellular organelles, which can produce functional disruptions or form bioconjugates with DNA (Gottschalk et al. 2011, Hoyt and Mason 2008).

Currently, there are insufficient data that have been published on the uses and presence of certain other NPs (Cu-NPs, ZnO-NPs) in textiles, cosmetics, or food (Chattopadhyay et al. 2010). Life cycle assessment (LCA) is an established tool for identifying environmental "hot spots" and for comparing products that provide the same services (Walser et al. 2011). Using LCA to assess NMs would assist in defining their impact on the environment, on human health and on other life forms; when performed LCA should address all production stages, products used and their environmental impact (Walser et al.2011, Meyer et al. 2011).

Statistical data have shown that socks can be washed 50-250 times during their lifespan (1-5 years), when washed once a week. Manufacturer of nAg-containing socks seek to ensure that the added nAg will last as long as possible and leach as slowly as possible. Meyer et al. performed 50 washing cycles on nAg socks, using nAg-free socks as the control. Walser et al. studied the life cycle of nAg T-shirts, and found the amount of $\mathrm{nAg}$ released was $67 \%$ (average content: $31-2,600 \mathrm{ppm}$ ) from the sum of all washing cycles. As much as $71 \mathrm{wt} \%$ of the examined $\mathrm{nAg}$ was insoluble silver. After release, it was discovered that the $\mathrm{nAg}$ had lost its toxic effect by binding with ligands present in the aqueous environment. The remaining silver (29\%) was soluble. Both the release rate of the NPs and their effect on aquatic organisms depended on the particular washing process and the presence of detergents and foaming agents.

Benn and Wasterhoff (2008) performed a study in which the total $\mathrm{nAg}$ content in textiles was evaluated. They also estimated the nAg content released by NMs in the washing process. They started by mineralizing seven types of socks that contained $\mathrm{nAg}$ (content between $0.9-1,358 \mathrm{ppm}$ ). The cumulative $\mathrm{nAg}$ content from four $24 \mathrm{~h}$ washing cycles was determined by using ICP-OES (Inductively Coupled Plasma Optical Emission Spectroscopy), and results ranged from 0.02 to $1.8 \mathrm{ppm}$, depending on the sock type. Zhang et al. (2009a) examined cotton socks that had an $\mathrm{nAg}$ content between 88-170 ppm. These socks had been subjected to 5, 10, and

Table 3. Metal concentrations in waters vs. Polish and US EPA regulatory standards

\begin{tabular}{|c|c|c|c|c|c|}
\hline \multirow{3}{*}{$\begin{array}{l}\text { Metal concentration } \\
{[\mathrm{ppm}]}\end{array}$} & \multicolumn{2}{|c|}{$\begin{array}{c}\text { Polish regulations } \\
\text { (Dz.U. 2008'; Dz.U. 2011²) }\end{array}$} & \multicolumn{3}{|c|}{ US EPA ${ }^{3,4}(2002 ; 2009)$} \\
\hline & \multirow{2}{*}{$\begin{array}{l}\text { Surface } \\
\text { water }\end{array}$} & \multirow{2}{*}{$\begin{array}{l}\text { Ground } \\
\text { water }\end{array}$} & \multirow{2}{*}{$\begin{array}{l}\text { Surface } \\
\text { water }\end{array}$} & \multicolumn{2}{|c|}{ Drinking water } \\
\hline & & & & $\begin{array}{l}\text { Primary } \\
\text { standard }\end{array}$ & $\begin{array}{l}\text { Secondary } \\
\text { standard }\end{array}$ \\
\hline $\mathrm{Ag}$ & $\leq 0.005$ & - & 0.003 & - & 0.100 \\
\hline $\mathrm{Cu}$ & $<0.050$ & $0.001-0.002$ & 1.300 & 1.300 & 1.000 \\
\hline $\mathrm{Zn}$ & $\leq 1.000$ & $0.005-0.020$ & 0.120 & - & 0.100 \\
\hline $\mathrm{Ti}$ & $\leq 0.050$ & - & - & - & - \\
\hline
\end{tabular}

${ }^{1}$ Dziennik Ustaw (Dz.U.) (2008) No. 143, Pos. 896; ${ }^{2}$ Dziennik Ustaw (Dz.U.) (2011) No. 257, Pos. 1545; ${ }^{3}$ US EPA (2002); ${ }^{4}$ US EPA (2009).

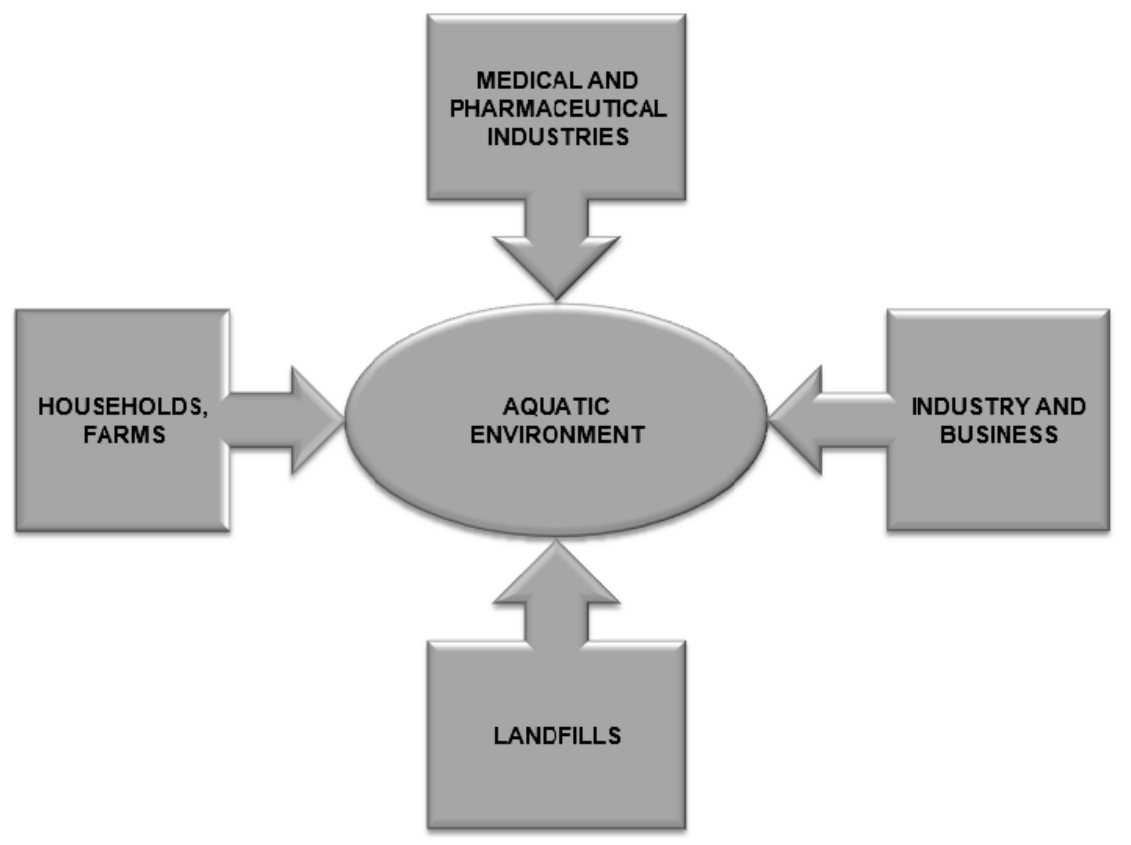

Fig. 1. The sources of occurrence of nanomaterials in the aquatic environment 
20 washing cycles. After each washing cycle, the nAg amounts released were 85,83 , and $82 \mathrm{ppm}$, respectively. The released $\mathrm{nAg}$ amount depended on such factors as process conditions (temperature, $\mathrm{pH}$ level, ionic strength), textile manufacture factors (fibre composition, $\mathrm{nAg}$ content, synthesis method) or the bleaching agent added. Nowack et al. (2009) investigated the $\mathrm{nAg}$ content released during the washing of 8 sock types. After the first cycle, the released $\mathrm{nAg}$ concentrations (from the textile structure) ranged from 1.3 to $377 \mathrm{ppm}$ (process conditions: $\mathrm{pH}=10$; surfactant presence: Sodium dodecyl sulfate (SDS) $0.1 \mathrm{~g} / \mathrm{L}$ ). After the second washing cycle, the amounts of released nAg decreased to 0.35 to $129 \mathrm{ppm}$. After washing a bleaching agent was added and the $\mathrm{nAg}$ content increased again to a range of 2.7 and 180 ppm. Farkas et al. (2011) studied the total $\mathrm{nAg}$ concentration in T-shirts and discovered that they contained from 0.7 to $4.7 \mathrm{ppm}$ of $\mathrm{nAg}$. In this same study, the sample filtrate from one washing cycle contained between 0.003 to $0.025 \mathrm{ppm}$ of released $\mathrm{nAg}$.

\section{Nanomaterials interaction in aquatic environment}

Interaction of nanoparticles with environmental elements is still unknown. Due to their unique physicochemical properties, NPs are capable of accumulating in solid elements of the aquatic environment or in living organism tissues. The insoluble nanocolloids are resistant to degradation and, can be deposited in the silt slurry of rivers or may accumulate into larger agglomerates. The mobility of NPs in aqueous environment depends on the $\mathrm{pH}$ level, ionic strength, presence of clay minerals, and organic matter. NPs are also subject to aggregation, precipitation, and deposition on biofilms and sediments, and the degree to which this may occur depends on the amounts and persistence of NMs in the aquatic environment (Brinkmann et al. 2003).

\section{Nanometals \\ Nanosilver}

The positive charge present on the nAg surface is strong. It causes the adsorption of nucleophiles or organic compounds. Consequently, nAg can sorb impurities (Sondi and Salopek-Sondi 2004, Liu et al. 2003). Recent studies show that the activity of NMs varies with their life cycle stage (Fouqueray et al. 2012). The nanosilver particles (Ag-NPs) may cause the suspension and immobilization of river particles (i.e. clay minerals, hydrated iron oxides, and organic matter). They can also produce the soil solution, which can greatly hinder the transport of NPs. The Ag-NPs are precipitated in seawater of high salinity and with high levels of chloride ions $(\mathrm{AgCl})$. What is more, they form larger agglomerates due to the modification of surface charges. Humic and fulvic acids, which have negative surface charges, increase the nAg stability in an aqueous solution and amplify the mobility of nAg. They also immobilize silver chloride anions and contribute to the change in their physicochemical properties (Peralta-Videa et al. 2011, Sagee et al. 2012). Similar effects of the Ag-NPs agglomeration are observed when the $\mathrm{Ca}^{2+}$ or $\mathrm{Na}^{+}$solutions are added into the $\mathrm{nAg}$ solution. The ionic strength rises together with the increasing $\mathrm{Ca}^{2+}$ or $\mathrm{Na}^{+}$concentrations. Divalent cations, such as $\mathrm{Ca}^{2+}$ (occurring in lower concentrations than $\mathrm{Na}^{+}$ions), provoke electrostatic destabilization and agglomeration, with organic molecules present in the solution (Delay et al. 2011, Liu et al. 2013). In the aqueous environment, $\mathrm{nAg}$ form aggregates and networks or clusters that are influenced by the increasing ionic strength and the presence of surfactants or humic acids (Bae et al. 2011, Ratte 1999). The studies of the nAg adsorption on a cotton fabric surface treated with three different hydroxide solutions (i.e. $\mathrm{LiOH}, \mathrm{NaOH}$ and $\mathrm{KOH}$ ) show that the adsorbed nAg contents in textiles were 6,000,17,000, and 20,000 ppm, respectively. The adsorbed nAg content rose when the solution basicity increased. The cotton treated with metal hydroxides instigated the activity of hydroxyl groups present in the cellulose structure (Yazdanshenas and Shateri-Khalilabad 2012).

\section{Nanogold}

The nanogold particles (Au-NPs) can be stabilized with citrate according to the Turkevich method (Rostek et al. 2011), which can significantly influence their fate and mobility in the aquatic environment. The humic acid addition prevents the agglomeration of NPs into larger units and stabilizes the suspension. A humic acid mixture introduces a modification to the Ag-NPs surface or behaves as an organic stabilizer substitute (Lee and Ranville 2012). After entering into the aquatic environment, Au-NPs are adsorbed onto the organic components (fulvic and humic acids). Their behaviour and ecotoxicity will differ as they depend on the prevailing conditions, such as the $\mathrm{pH}$ level, which affects the nanoparticle stability (Diegoli et al. 2008). In an acidic environment $(\mathrm{pH}<4)$, the dominant $\mathrm{nAu}$ compound present in aqueous solutions is $\mathrm{AuCl}_{2}$. When $\mathrm{pH}>6$, the most numerous ions are $\mathrm{AuCl}(\mathrm{OH})_{3}^{-}$, whereas at $\mathrm{pH}>9 \mathrm{Au}(\mathrm{OH})_{4}^{-}$ions dominate. The most toxic $\mathrm{Au}$ ions in aquatic organisms are $\mathrm{AuCl}(\mathrm{OH})_{3}^{-}$(Lapresta-Fernandez et al. 2012). The interaction with organic matter stabilizes both $\mathrm{Au}-$ -NPs and the temperature. When the temperature goes up, the $\mathrm{Au}-\mathrm{NPs}$ aggregation also increases. At $55^{\circ} \mathrm{C}$, Au-NPs achieve the highest stability. A strong negative charge on the surface of Au-NPs results from their binding with organic matter. The strong charge leads to an increase in the reactivity of Au-NPs and electrophoretic mobility. The behaviour of Au-NPs in the sea and ocean waters and inside microorganisms can be explained with their mobility (Lapresta-Fernandez et al. 2012).

\section{Nanocopper}

The isoelectric point of copper nanoparticles (Cu-NPs) is in the $\mathrm{pH}$ range of 7.5 to 8.5 . The rising $\mathrm{pH}$ level also increases the $\mathrm{Cu}-\mathrm{NPs}$ agglomeration. At high temperatures, $\mathrm{nCu}$ agglomerates form to a lesser extent due to the chaotic motion of the molecules (Rispoli et al. 2010). The organic matter presence results in the inhibition of mobility and prevents the formation of a bond between $\mathrm{Cu}-\mathrm{NPs}$ and metal compounds due to the repulsion forces. A humic acid mixture in reaction with $\mathrm{Cu}-\mathrm{NPs}$ brings about the electrostatic and steric stabilization of the Cu-NPs. Consequently, their mobility is limited (Jones and $\mathrm{Su} 2012$ ).

\section{Metal oxide nanoparticles}

\section{Zinc oxide nanoparticles}

In the aquatic environment, the $\mathrm{nZnO}$ forms are highly dependent on the $\mathrm{pH}$ levels, which are related to the surface charge and interparticle electrostatic repulsion. The point of zero-charge of $\mathrm{nZnO}$ is between $\mathrm{pH} 8$ and 9. At higher 
pH levels, $\mathrm{Zn}$ compounds $\left(\mathrm{ZnOH}^{+}\right.$and $\left.\mathrm{Zn}(\mathrm{OH})_{2}\right)$ dominate (Sheela et al. 2012, Zhou and Keller 2010, Petosa et al. 2012). The activity of hard base on the ZnO-NPs surface results in the formation of $\mathrm{Zn}^{2+}$ ions through the covalent bond (Rhodes et al. 2010). The zeta potential makes an important factor in the change in nanoparticle surface charges. With the decrease in the zeta potential and electrostatic or steric repulsions between the $\mathrm{ZnO}-\mathrm{NPs}$, the ionic strength rises. The aggregation of $\mathrm{ZnO}-\mathrm{NPs}$ increases with the rising ionic strength because the electrostatic forces act between NPs. To prevent the aggregation of $\mathrm{ZnO}-\mathrm{NPs}, \mathrm{CaCl}_{2}$ or $\mathrm{NaCl}$ is added. Jiang et al. (2012, 2012a) conclude that the stabilization of the $\mathrm{ZnO}-\mathrm{NPs}$ solution can be controlled with divalent cations, such as $\mathrm{Ca}^{2+}$. However, Zhang et al. (2007) observe that the presence of natural organic matter (NOM) or $\mathrm{Ca}^{2+}$ ions can stabilize the ZnO-NPs dispersion. Consequently, the surface potential increases, whereas negative charges are neutralized and the ionic strength rises. Humic acids, which naturally occur in the aquatic environment, produce the increase in the nanoparticle transport, mobility and dispersion. The synthesis methods and environmental conditions have an impact on the nanoparticle behaviour (Ben-Moshe et al. 2010).

\section{Titanium dioxide nanoparticles}

Titanium dioxide nanoparticles $\left(\mathrm{TiO}_{2}-\mathrm{NPs}\right)$ are used as a factor in the degradation processes, which allows for an easier distribution and mineralization of organic compounds (Rincon et al. 2004). As all NMs, nanotitanium (IV) oxide has a large surface area. As a result, it is characterized by increased reactivity, mobility, and ability to absorb impurities. Titanium nanodioxide stability depends on the zeta potential value and organic additives or ionic strength. The stability of the $\mathrm{TiO}_{2}$-NPs suspension can be controlled with various ions present in the solution. $\mathrm{Na}^{+}$or $\mathrm{SO}_{4}^{2-}$ ions are better flocculant agents than $\mathrm{Ca}^{2+}$ and $\mathrm{Cl}^{-}$ions when the $\mathrm{pH}$ levels of the suspension are lower than the point of the zero-charge of NPs. The isoelectric point of $\mathrm{TiO}_{2}-\mathrm{NPs}$ is in the $\mathrm{pH}$ range of 3.5 to 8.0 . At this $\mathrm{pH}$ range, $\mathrm{TiO}_{2}-\mathrm{NPs}$ exhibit the greatest bioavailability for microbial cells (Skocaj et al. 2011, Fernandez-Nieves et al. 1999). The sorption capacity of $\mathrm{TiO}_{2}-\mathrm{NPs}$ depends mainly on the surface structure, shape and crystal form, particle size, and surface energy. Titanium nano-oxides can bind arsenic, selenium, and thallium compounds ( Zhang et al. 2009, Tan et al. 2007, Jegadeesan et al. 2010, Zhang et al. 2009b). The binding of the thorium, Th(IV), compounds on the titanium nanodioxide surface largely depends on the $\mathrm{pH}$ level $(>6)$ and, to a lower extent, on the solution ionic strength. The bond formation mechanism is mainly based on the complexes (Tan et al. 2007). The binding with selenium, $\mathrm{Se}(\mathrm{IV})$, compounds is formed at similar $\mathrm{pH}$ levels (2-6), but the sorption process of thallium, Tl(III), is formed at the $\mathrm{pH}$ level of 4.5 . $\mathrm{TiO}_{2}$-NPs are able to bind $96 \%$ of the selenium compounds and nearly $100 \%$ of the thallium, Tl(III), compounds from aqueous solutions (Zhang et al. 2009, Zhang et al. 2009b). Metal ions and organic compounds form complexes in the presence of humic and fulvic acids. In an acidic medium ( $\mathrm{pH} 3$ ), NPs form a positive charge on the $\mathrm{TiO}_{2}$ surface, which increases the adsorption of negatively charged humic acids (Tan et al. 2007). Importantly, such pH levels of surface waters seldom occur in the natural environment (in water infiltration through mining landfills).

\section{Iron oxide nanoparticles}

The reactivity of iron oxide nanoparticles $\left(\mathrm{Fe}_{\mathrm{x}} \mathrm{O}_{\mathrm{y}}-\mathrm{NPs}\right)$ results in their toxicity to microorganisms. Their strong reactivity and ability to aggregate are neutralized with the organic matter stabilization (humic acids have a strong affinity for the iron oxide nanoparticles) or polymer addition (Pawlett et al. 2013). The presence of solids and organic matter in the aquatic environment increases the durability of iron nanoparticles through the inactivation of the surface charge and creation of larger agglomerates. After longer presence in the soil, iron nanoparticles are oxidized to $\mathrm{Fe}_{\mathrm{x}} \mathrm{O}_{\mathrm{y}}-\mathrm{NPs}$, which are deposited in the pore (Adeleye et al. 2013). $\mathrm{Fe}_{\mathrm{x}} \mathrm{O}_{\mathrm{y}}$-NPs are amphoteric and often occur in the hydrate form in the environment. They can react both with $\mathrm{H}^{+}$and $\mathrm{OH}^{-}$ions (depending on the $\mathrm{pH}$ level), and they can form positive $\mathrm{FeOH}$ and negative $\mathrm{FeO}$ ions. According to the London-van der Waals theory, the binding formation present in the environmental compounds is the presence of the electrostatic interaction between different charges and the formation of complex compounds between iron nano-oxides and organic ligands (Illes and Tombacz 2006). Iron nano-oxides (magnetite) are used as sorbents of toxic compounds, such as arsenic (Shipley et al. 2011), selenium (Gonzalez et al. 2012), palladium, rhodium, platinum (Uheida et al. 2006), and uranium (Das et al. 2010). $\mathrm{Fe}_{\mathrm{x}} \mathrm{O}_{\mathrm{y}}$-NPs exhibit the greatest ability to bind ions at low $\mathrm{pH}$ levels (2-4). Selenium compounds are bonded with the greatest ability by $\mathrm{Fe}_{\mathrm{x}} \mathrm{O}_{\mathrm{y}}$-NPs at the $\mathrm{pH}$ level of $2-4$. The isoelectric point of $\mathrm{Fe}_{\mathrm{x}} \mathrm{O}_{\mathrm{y}}$-NPs occurs when the $\mathrm{pH}$ level is about 7. The increase in the $\mathrm{pH}$ level causes the formation of a negative charge on the surface of NPs as well as an increased affinity for the binding of cations (Gonzalez et al. 2012).

\section{Toxicity of nanoparticles to aquatic microorganisms}

The presence of NMs in the environment is hazardous for microorganisms as NPs distort their functions. The negative impact of NPs on human health is not fully understood. NPs are small and they can cross the blood-brain barrier and penetrate the organism through skin or deposit in the respiratory organs (Łebkowska et al. 2011). The released NPs $\left(\mathrm{TiO}_{2}\right.$ and $\left.\mathrm{Ag}\right)$ are accumulated in the tissues of aquatic animals in the structures of plants, within the phytoplankton, and in the roots of aquatic plants (Bradley et al. 2011, Cockburn et al. 2012). Currently, the researchers are looking for effective ways to disinfect cosmetic and pharmaceutical or medical devices, in which the microbiological purity is crucial. The applied disinfectants contain additional foaming agents, surfactants, or aggressive biocides (Wzorek and Konopka 2007). The antibacterial properties of nanostructures reveal their reactivity and presence of a strong surface charge. The mechanism is not fully understood, but it probably involves the adsorption of positively charged NPs (nAg) to the negatively charged microorganism cell wall. As a result, the cellular enzymes are inhibited and the cellular respiration process is impaired, which leads to death (Choi et al. 2008). In the aquatic environment, the NPs of metal or metal oxides can form reactive oxygen species present in the $\mathrm{OH}^{-}, \mathrm{O}_{2}$, and $\mathrm{H}^{+}$solutions. Positively charged NPs can interact with negatively charged bacteria cell wall due to the 
electrostatic forces. Antibacterial metal ions can form under the influence of radicals. The ions are released into aquatic solutions (Fig. 2) (Guerard et al. 2009, Espitia et al. 2012). Furthermore, NPs have a catalytic effect, which generates the production of free radicals invading the thiol groups of amino acids. The great challenge is the resistance of bacteria present in water and wastewater to antibiotics (no treatment system in Poland is developed to remove these contaminants). The occurrence of antibacterial NPs in sewage can generate changes in the quality of the final products of the treatment process. Biogeochemical processes can be disrupted through the interaction of NPs with the bacterial enzymes, which leads to irreversible changes in the environment (Das et al. 2012). Liang et al. (2010) draw similar conclusions in the study of the $\mathrm{nAg}$ interactions with activated sludge bacteria. NPs inhibit the ATP synthesis process in bacterial cells. The 1 ppm nAg concentration causes about $40 \%$ inhibition of the nitrification process. The presence of ligands and their types $\left(\mathrm{SO}_{4}^{2-}, \mathrm{S}^{2-}, \mathrm{PO}_{4}^{3-}, \mathrm{Cl}^{-}\right.$, and EDTA') have an impact on the $\mathrm{nAg}$ toxicity. The problem is investigated in the study (Choi et al. 2008). The presence of $S^{2-}$ ions in the solution reduces the nAg toxicity by $80 \%$. This fact is also related to the bond between ions as well as formation of new compounds or the $\mathrm{Ag}_{\mathrm{x}} \mathrm{S}_{\mathrm{y}}$ precipitation, which reduces the $\mathrm{nAg}$ mobility.

Table 4 presents toxic concentrations of the most popular NPs in relation to the microorganisms most frequently occurring in the aquatic environment. The divergence of results in the determination of the toxic NMs doses is associated with a variety of NM synthesis methods, physicochemical properties (particle size, compound type, nanoparticle shapes, and specific surface area), and process conditions ( $\mathrm{pH}$ level, temperature, ionic strength, presence of organic compounds) (Marambio-Jones and Hoek 2010, Becker et al. 2011, Farre et al. 2011).

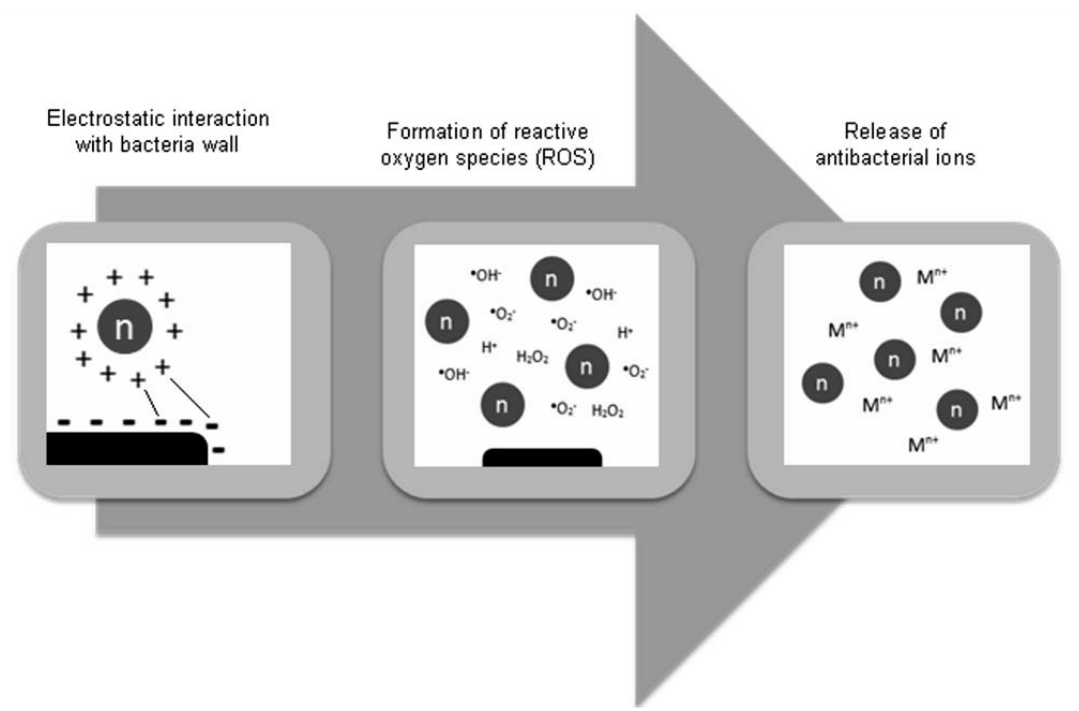

Fig. 2. Mechanism of released antibacterial metal ions from nanoparticles solution (Espitia et al. 2012)

Table 4. Concentrations of nanomaterials that are toxic to aquatic microorganisms

\begin{tabular}{|c|c|c|c|c|c|c|c|c|}
\hline \multirow{3}{*}{ Organisms } & & \multicolumn{7}{|c|}{ Toxic concentrations of nanomaterials [ppm] } \\
\hline & & \multicolumn{3}{|c|}{ Metal nanoparticles } & \multicolumn{4}{|c|}{ Metal oxides nanoparticles } \\
\hline & & $\mathrm{nAg}$ & $\mathrm{nAu}$ & $\mathrm{nCu}$ & $\mathrm{nCuO}$ & $\mathrm{nZnO}$ & $\mathrm{nTiO}_{2}$ & $\mathrm{nFe}_{\mathrm{x}} \mathrm{O}_{\mathrm{y}}$ \\
\hline \multirow{4}{*}{ Bacteria } & E. coli & $0.45^{1}$ & $>30^{2}$ & $3,349^{3}$ & $50^{4}$ & $1,000^{5}$ & $\begin{array}{c}100^{6} \\
5,000^{5}\end{array}$ & $24^{7}$ \\
\hline & S. aureus & $20^{1}$ & & $250^{8}$ & $100^{4}$ & $10^{5}$ & & \\
\hline & B. subtilis & & $>30^{2}$ & $2,820^{3}$ & & & $\begin{array}{l}1,000^{5} \\
2,000^{5}\end{array}$ & \\
\hline & V. fischeri & & & & $\begin{array}{c}79^{9} \\
200^{9}\end{array}$ & $1-2^{10}$ & $>20,000^{11}$ & $240^{12}$ \\
\hline \multirow{2}{*}{$\begin{array}{l}\text { Daphnia magna } \\
\text { and } \\
\text { Lemna minor }\end{array}$} & D. magna & $0.004^{13}$ & & & $\begin{array}{c}94^{14} \\
3^{9} \\
54^{13} \\
\end{array}$ & $3^{9}$ & $>20,000^{11}$ & $2^{7}$ \\
\hline & L. minor & $\begin{array}{c}14^{15} \\
0.005^{16}\end{array}$ & & & & & & \\
\hline
\end{tabular}

${ }^{1}$ Cho et al. 2005, ${ }^{2}$ Balasubramanian et al. 2010, ${ }^{3}$ Yoon et al. 2007, ${ }^{4}$ Jadhav et al. 2012, ${ }^{5}$ Adams et al. 2006, ${ }^{6}$ Manese et al. $1999,{ }^{7}$ Garcia et al. 2011, ${ }^{8}$ Ren et al. 2009, ${ }^{9}$ Heinlaan et al. 2008, ${ }^{10}$ Hernandez-Sierra et al. 2008, ${ }^{11}$ Strigula et al. 2009, ${ }^{12}$ Chen et al. 2011, ${ }^{13} \mathrm{Jo}$ et al. 2012, ${ }^{14} \mathrm{Blinova}$ et al. 2010, ${ }^{15} \mathrm{Kim}$ et al. 2011, ${ }^{16}$ Gubbins et al. 2011. 


\section{Metal nanoparticles}

\section{Nanosilver}

$\mathrm{nAg}$ with strong biocidal activity is the most popular nanometal. Small Ag-NPs form bonds with proteins and cause the denaturation and disruption of cells. The electrostatic interaction between positively charged Ag-NPs and negatively charged microbial cells can lead to the impairment of the bacteria life processes (Sondi and Salopek-Sondi 2004).

The nAg agglomerates on a silica (present in textile fibres) have strong antibacterial properties. Even after 10 washing cycles, the biocidal properties are still strong against the most common microorganisms found in wastewater (Jasiorski et al. 2009). However, the toxicity of Ag-NPs depends on their size. Smaller Ag-NPs (particle size: $9.2 \mathrm{~nm}$ ) have stronger toxicity when compared with larger ones (particle size: 62 $\mathrm{nm})$. It results from the Ag-NPs ability to chemisorb on smaller particles contained in the cell wall structures of microorganisms. The smaller the Ag-NPs are, the larger the ratio of surface area to mass becomes (Lok et al. 2007). The easiness of the nanoparticle binding with the aquatic organism proteins also depends on the NPs nature. The increase in the NM hydrophobicity leads to the increase in the capacity of the protein absorption (Zhang et al. 2012, Landsiedel et al. 2012). At present, chlorine, iodine, bromine, and ozone compounds are used for water disinfection (Pedahzur et al. 1997, Gangadharan et al. 2010, Mohmood et al. 2013). Ag-NPs can also be used as water disinfectant due to their strong biocidal effect observed in organisms such as Escherichia coli (Choi et al. 2008, Cho et al. 2005, Lee et al. 2009, Sondi and Salopek-Sondi 2004, Wang et al. 2012, Radziga et al. 2013), Staphylococcus aureus (Choi et al. 2008), Caenorhabditis elegans (Kim et al. 2012), Marinobacter sp. (Sinha et al. 2011), Lemna minor (Gubbins et al. 2011, Kim et al. 2011), Bacillus subtilis (Lee et al. 2009, Wang et al. 2012), Saccharomyces cerevisiae, Trichosporon beigellii, Candida albicans (Kim et al. 2009), Ceriodaphnia dubia (Glover and Wood 2004), Daphnia magna (Glover and Wood 2004, Jo et al. 2012, Bianchini et al. 2005, Blinova et al. 2013), Thamnocephalus platyurus(Blinova et al. 2013), Agrobacterium tumefaciens (Wang et al. 2012), and Pseudomonas aeruginosa, and Serratia proteamaculans (Radziga et al. 2013).

In the study (Hebeish 2011), the $50 \mathrm{ppm} \mathrm{nAg} \mathrm{concentration}$ used to impregnate textiles showed $96 \%$ inhibition of the bacterial growth for $E$. coli and $S$. aureus. The $\mathrm{nAg}$ solutions coming from samples of impregnated textiles used in 5 washing cycles inhibited the microorganism growth by $71-74 \%$. After 10 washing cycles, the nAg solutions caused $61 \%$ inhibition of $E$. coli and $68 \%$ of $S$. aureus. After the $20^{\text {th }}$ washing cycle, the inhibition of $E$. coli and $S$. aureus caused by the nAg solution was $57 \%$ and $61 \%$, respectively. The $\mathrm{nAg}$ on an organic medium was used to impregnate the fabric for comparison. It turned out that at the $50 \mathrm{ppm}$ nAg concentration, the bacterial growth inhibition was more than $90 \%$, even after 20 washing cycles. In relation to nitrifying bacteria, the lowest substance concentration that caused negative effects on the microorganism functions, was determined at the level of 0.01-0.07 ppm, depending on the type and chemical composition of the water used in the experiment. However, the toxic $\mathrm{nAg}$ concentration required for $E$. coli was $0.45 \mathrm{ppm}$. $S$. aureus is another bacteria hazardous to human health. The effects of the nAg concentrations of 5, 10, and $20 \mathrm{ppm}$ were examined. The inhibition of the entire $S$. aureus colony growth took place in the $10 \mathrm{ppm}$ concentration and after only 3.3 hours. On the other hand, the $20 \mathrm{ppm}$ concentration resulted in the $99.9 \%$ inhibition of $S$. aureus growth observed after 4 hours (Cho et al. 2005). Different results were obtained for Klebsiella pneumoniae. In the solutions of fabrics containing Ag-NPs, the bacteria inhibition was $96 \%$ after 5 washing cycles. After 20 washing cycles, it was only $30 \%$ (Lee et al. 2003).

Moreover, the toxic Ag-NPs properties were observed for aquatic organisms. The $0.0005 \mathrm{ppm}$ Ag-NPs concentration induced a toxic effect in half of the $C$. dubia organisms. The experimental conditions and the physicochemical properties of the water used for toxicity tests (i.e. zeta potential, $\mathrm{pH}$ level, and organic matter) affected the value of the Ag-NPs toxicity. The highest toxicity is associated with a low zeta potential and low electrophoretic mobility (McLaughlin et al. 2012). In the $24 \mathrm{~h}$ test, the inhibition of half of the D. magna organisms required the $0.004 \mathrm{ppm}$ Ag-NPs concentration (Jo et al. 2012). Macrophytes, such as duckweed (L. minor), are characterized by rapid growth, easy adaptation to environmental conditions, and wide tolerance ( $\mathrm{pH} 4.5-8.3$ ). These organisms are used to remove mineral and organic contaminants. For duckweed, the Ag-NPs toxicity was observed at the 14 ppm concentration, whereas the lowest concentration in which toxicity changes were observed (chlorosis and necrosis) was 1 ppm of Ag-NPs. The Ag-NPs bioaccumulation in the eyelashes and body after 5 days exposure with 10,20 , and 40 ppm concentrations is $55 \%$, $65 \%$, and $19 \%$, respectively (Kim et al. 2011). Other literature reports show that the $0.005 \mathrm{ppm}$ Ag-NPs concentration can lead to the $80 \%$ inhibition of the duckweed growth (Gubbins et al. 2011).

The silver sulphide nanoparticles (particle size: 5-20 nm) were identified in the sewage sludge. The NPs contents ranged between 1.9 and 856 ppm (Kim et al. 2010). The identified Ag-NPs could provoke the inhibition of the bacterial enzymes responsible for the cell cycle and metabolism Ag-NPs may also affect the structure of the activated sludge flocs and the biofilm formation (Sheng and Liu 2011).

\section{Nanogold}

Au-NPs are regarded as model molecules for carrying out research on the transport and bioaccumulation in living organisms. Insoluble $\mathrm{nAu}$ is relatively nontoxic when compared to other nanometals (Lee et al. 2012). The Au-NPs surfaces are modified with carboxylic acids to improve the stability of Au-NPs. Such treatment also prevents agglomeration and precipitation and improves the applicability of Au-NPs in medicine and electronics. Importantly, the process involves an additional load for the environment (Tedesco et al. 2010, Rostek et al. 2011). The toxicity and cytotoxicity tests of nAu mainly concern aquatic organisms. For mussel (Mytilus edulis), the $0.75 \mathrm{ppm} \mathrm{nAu}$ concentration (particle size: $13-15 \mathrm{~nm}$ ) disturbed the enzymatic activity (Lapresta-Fernandez et al. 2012, Tedesco et al. 2010). The 17 ppm nAu concentration (particle size: $5-10 \mathrm{~nm}$ ) increased the production of reactive oxygen species for rainbow trout (Oncorhynchus mykiss) (Farkas et al. 2010). In relation to E. coli and B. subtilis, nAu showed no toxic changes, even at $30 \mathrm{ppm}$ concentrations (Balasubramanian et al. 2010). In the literature, there are very few reports on the toxicity of Au-NPs to the aquatic microorganisms and bacteria present in the aquatic 
environment. It can probably be explained with the low $\mathrm{nAu}$ toxicity. However, nAg can have different physicochemical properties and biological activity due to different methods of its synthesis. Therefore, it seems appropriate to determine the toxicity of Au-NPs.

\section{Nanocopper}

$\mathrm{nCu}$ is an antibacterial and antifungal agent that is as strong as $\mathrm{nAg}$. Due to its small size it can complete the cell lysis shortly after entering a living organism (Yoon et al. 2007). With the inhibition of the proper enzyme functions, oxidative stress and cellular respiration process, microorganisms die (Raffi et al. 2010). The Cu-NPs are becoming increasingly used in everyday products. Their toxicity should not be disregarded. It is still an issue due to the different $\mathrm{nCu}$ properties and behaviour when compared to the ionic form. The toxicity of $\mathrm{Cu}-\mathrm{NPs}$ to living organisms is higher than the toxicity of $\mathrm{Cu}$ ions (Pradhan et al. 2012). In addition, the $\mathrm{Cu}-\mathrm{NPs}$ cause toxic effects on organisms in the aquatic environment. Different factors (synthesis method and dispersion of nanoparticles, size, initial solution concentration, sample preparation) affect the interaction and have a negative impact on living organisms. During the 24 hour exposure of D. magna to $\mathrm{Cu}-\mathrm{NPs}$, half of the tested organisms were immobilized by the toxicity of the $\mathrm{Cu}-\mathrm{NPs}$ solution (particle size: $50 \mathrm{~nm}$ ). The toxic effect was observed for the concentration range between $55 \mathrm{ppb}$ ( $100 \mathrm{ppm}$ concentration of $\mathrm{Cu}-\mathrm{NPs}$, filtered at $0.1 \mu \mathrm{m}$, sonicated for 120 minutes) and 3 ppm (1000 ppm concentration of $\mathrm{Cu}-\mathrm{NPs}$, unfiltered, sonicated for 120 minutes). The unfiltered sample with a higher concentration of $\mathrm{Cu}-\mathrm{NPs}$ had the ability to form aggregates and larger clusters that did not exhibit toxicity. The smaller $\mathrm{Cu}-\mathrm{NPs}$ that easily penetrate living organisms could bind with enzymes and cellular organelles, leading to toxic and irreversible changes (Jo et al. 2012).

The biocidal activity of Cu-NPs can be observed for the majority of common bacteria in the aqueous environment. These include E. coli (Esteban-Cubillo et al. 2006, Jadhav et al. 2011, Ramyadevi et al. 2012, Yoon et al. 2007), S. aureus (Esteban-Cubillo et al. 2006, Jadhav et al. 2011, Ren et al. 2009), B. subtilis (Yoon et al. 2007), Vibrio fischeri (Heinlaan et al. 2008), and P. aeruginosa and Proteus (Ren et al. 2009). For E. coli and B. subtilis, toxic concentrations of $\mathrm{Cu}-\mathrm{NPs}$ (particle size:100 nm) were 3,349 and 2,820 ppm, respectively, with the $90 \%$ antibacterial effect (Yoon et al. 2007). The $\mathrm{Cu}-\mathrm{NPs}$ (particle size: $22.4-94.8 \mathrm{~nm}$ ) at a $250 \mathrm{ppm}$ concentration inhibited the growth of $S$. aureus, whereas a 2,500 ppm concentration inhibited the growth of $P$. aeruginosa and Proteus. The differences in the $\mathrm{nCu}$ concentrations, which demonstrate the toxic effects, depend on the nanoparticle size, bioavailability of $\mathrm{Cu}^{2+}$ ions, synthesis method and type of test microorganisms (Ren et al. 2009).

\section{Metal oxide nanoparticles}

\section{Zinc oxide nanoparticles}

The $\mathrm{ZnO}-\mathrm{NPs}$ solution in aquatic media can form $\mathrm{Zn}^{2+}$ ions, which are very toxic to living organisms. The $\mathrm{Zn}$ ions can bind with sulfhydryl (-SH) groups of enzymes and cause cell damage and blood circulation disturbance. $\mathrm{Zn}^{2+}$ ions pose a threat to aquatic microorganisms. After entering through a cell membrane, the released $\mathrm{Zn}^{2+}$ ions can generate reactive oxygen species (ROS) that disturb the work of microorganism organelles (Wilson et al. 2007, Liu et al. 2013). The antibacterial activity of $\mathrm{ZnO}-\mathrm{NPs}$ depends on the aggregation, size and concentration. Smaller ZnO-NPs and agglomerates have a larger antibacterial effect than larger ones (Zhang et al. 2007). The study (Ramani et al. 2012) shows that ZnO-NPs, which causes $99 \%$ growth inhibition, can be an antibacterial agent against $S$. aureus, B. subtilis, Streptococcus pneumoniae, Streptococcus agalactiae, K. pneumoniae, Salmonella typhi, E. coli, and P. aeruginosa. ZnO-NPs demonstrates bacteriostatic properties in the presence of both the gram-negative and gram-positive bacteria (Narayanan et al. 2012). The toxic concentration values differ. For example, the 10 ppm ZnO-NPs concentration inhibited $90 \%$ of B. subtilis. On the other hand, the 1,000 ppm concentration inhibited only $48 \%$ of $E$. coli. The differences in toxic effects arise from various properties of $\mathrm{ZnO}-\mathrm{NPs}$ (size, concentration, synthesis method, shape) and life functions of the bacteria (metabolism, cell physiology, cell wall structure) (Adams et al. 2006). In the study (Heinlaan et al. 2006), lower ZnO-NPs contents were observed for $V$. fischeri, where 1.1 to $1.9 \mathrm{ppm}$ concentrations resulted in the $69-93 \%$ inhibition. The minimal inhibitory concentration (MIC) and minimum bactericidal concentration of $\mathrm{ZnO}-\mathrm{NPs}$ for Streptococcus mutans were 500 ppm (Hernandez-Sierra et al. 2008). For aquatic microorganism, the ZnO-NPs were toxic to Spirodela polyrhiza at the $50 \mathrm{ppm}$ concentration $(\mathrm{Hu}$ et al. 2013), T. platyurus at $0.2 \mathrm{ppm}$ (Lethal Concentrations of $50 \%$ tested organisms in 24 hours - LC50, 24 hours), D. magna at 3 ppm (LC50, 24 hours) (Heinlaan et al. 2006), and Pseudokirchneriella subcapitata algae at $0.2 \mathrm{ppm}$ (total growth inhibition) (Aruoja et al. 2009).

\section{Titanium dioxide nanoparticles}

$\mathrm{TiO}_{2}$-NPs interact with $\mathrm{OH}^{-}$ions to form free radicals and with $\mathrm{O}$ atoms to form highly oxidizing ions, $\mathrm{O}^{2-}$ (Maness et al. 1999). Used as a disinfectant, nanotitanium dioxide causes toxic effects in bacterial microorganisms, viruses and fungi leading to the cell apoptosis. Nonetheless, the mechanism of the toxic activity of $\mathrm{TiO}_{2}$-NPs is not fully understood (Rincon et al. 2004, Larue et al. 2011). The $\mathrm{TiO}_{2}$-NPs released from sunscreens, pigments and inks are present in the aquatic and soil environments. Their sizes can decide on the toxicity effects of the NMs (Lewicka et al. 2011, Larue et al. 2011, Braydich-Stolle et al. 2009).

The toxic effects of $\mathrm{TiO}_{2}$-NPs (particle size: $25 \mathrm{~nm}$ ) on E. coli were observed at the $100 \mathrm{ppm}$ concentration level. The bacteria reduction was about $98 \%$. This confirms the antibacterial activity of $\mathrm{TiO}_{2}$-NPs (Manesse et al. 1999). $330 \mathrm{~nm} \mathrm{TiO}_{2}$-NPs caused a $72 \%$ growth inhibition of $E$. coli at the $5,000 \mathrm{ppm}$ concentration. The gram-positive B. subtilis exhibited greater sensitivity to the antibacterial activity of $\mathrm{TiO}_{2}$-NPs because the $1,000 \mathrm{ppm}$ concentration caused the $75 \%$ growth inhibition, while a 2,000 ppm concentration inhibited $99 \%$ of microorganisms (Adams et al. 2006). The $V$. fischeri and D. magna exhibited no toxic changes when treated with $\mathrm{TiO}_{2}$-NPs (particle size: 25-70 nm; 20,000 ppm concentration) (Heinlaan et al. 2008). Similar results were obtained in the studies on the $\mathrm{TiO}_{2}-\mathrm{NPs}$ toxicity. There was no toxic effect on the growth of $V$. fischeri and D. magna (Strigula et al. 2009). The toxicity of $\mathrm{TiO}_{2}-\mathrm{NPs}$ is relatively low when compared with antibacterial $\mathrm{Ag}$ and $\mathrm{Cu}-\mathrm{NPs}$. It can be assumed 
that the toxicity of $\mathrm{TiO}_{2}-\mathrm{NPs}$ is the lowest. Therefore, titanium nanodioxide is extensively used in medicine and pharmacy, where it has a major impact on human health.

\section{Iron oxide nanoparticles}

Due to their small size and active surface, iron oxide nanoparticles can interact with microorganisms. The gram-positive $B$. subtilis have a wider tolerance to the presence of iron nanoparticles than the gram-negative $E$. coli. This is the effect of either the repulsion forces acting between the positive charge on the iron nanoparticle surfaces and the positive charge on $B$. subtilis or the differences in the cell wall structure (presence of proteins and increased thickness of the cell wall) (Chenet al. 2011). The isoelectric point of $\mathrm{Fe}_{2} \mathrm{O}_{3}$-NPs is 7. Consequently, the attraction forces between microorganism cells and $\mathrm{Fe}_{2} \mathrm{O}_{3}$-NPs are dominant in an acidic medium ( $\mathrm{pH} 4)$ due to the positive surface charge of $\mathrm{Fe}_{2} \mathrm{O}_{3}$-NPs. On the other hand, the repulsion forces between $\mathrm{Fe}_{2} \mathrm{O}_{3}$-NPs and microorganisms are dominant in a basic medium (pH 10). The 24 ppm concentration of $\mathrm{Fe}_{2} \mathrm{O}_{3}$-NPs (particle size: $10 \mathrm{~nm}$ ) caused toxic changes in $E$. coli in an acidic medium ( $\mathrm{pH}$ 4). Aquatic organisms (D. magna) demonstrated a very strong sensitivity to $\mathrm{Fe}_{2} \mathrm{O}_{3}-\mathrm{NPs}$ (particle size: $6 \mathrm{~nm}$ ) and 50\% mortality in their presence at the concentration 2 ppm (García et al. 2011). In the bioluminescence test, $V$. fischeri displayed the growth inhibition in the $240 \mathrm{ppm}$ concentration (half maximal effective concentration - EC50) of $\mathrm{Fe}_{2} \mathrm{O}_{3}$-NPs (Chen et al. 2011).

\section{Copper oxide nanoparticles}

The antibacterial effect of CuO-NPs on E. coli and S. aureus was determined in experiments carried out on agar plates. The research was conducted for $5 \mathrm{~nm}$ particles and for 50 and $100 \mathrm{ppm}$ concentrations. A characteristic "halo" around the bacterial colonies was observed, which indicated the growth inhibition (Jadhav et al. 2011, Ramyadevi et al. 2012). CuO-NPs (particle size: 22.4-94.8 nm) caused growth inhibition of $S$. aureus at the $100 \mathrm{ppm}$ concentration, whereas the 5,000 ppm concentration inhibited the growth of $P$. aeruginosa and Proteus (Ren et al. 2009). The 79 ppm CuO-NPs (particle size: $30 \mathrm{~nm}$ ) concentration produced the inhibition of the $V$. fischeri population after a 30 minute exposure. In addition, the inhibition of the entire $V$. fischeri population occurred in the 200 ppm concentration of CuO-NPs (Heinlaan et al. 2008). CuO-NPs (particle size: $30 \mathrm{~nm}$ ) are toxic to D. magna. The 2 to $24 \mathrm{ppm}$ concentrations of CuO-NPs inhibited half the organisms of tested organisms within the 48 hour exposure (EC50, 48 hours). Toxic concentrations were dependent on the experiment conditions ( $\mathrm{pH}$ level, temperature, ionic strength, mineral composition of water) (Blinova et al. 2010). The concentration at $3 \mathrm{ppm}$ of CuO-NPs (particle size: $30 \mathrm{~nm}$ ) killed half of the D. magna organisms (LC50) within 48 hours. The mortality of half of the T. platyurus population in the 24 hour exposure (LC50) to $\mathrm{CuO}-\mathrm{NPs}$ required at 2 ppm concentration. The highest concentration of the $\mathrm{CuO}-\mathrm{NPs}$ with no observed toxic changes for both types of these aquatic organisms was $0.5 \mathrm{ppm}$ (Heinlaan et al. 2008).

\section{Conclusions}

Understanding issues such as the behaviour of NPs in the environment, their impact on aquatic organisms and their toxicity, helps to define the environmental risks and identify the new directions for their use. To protect the environment and living organisms, it is necessary to know the toxic doses of NPs and the mechanisms of their toxicity. Due to their large surface area and small size, NPs have strong chemical reactivities. Because of these properties, NPs are widely used in industry and technology. Due to their production and use, NPs are released into the environment. This generates the so-called nanocontaminants, which can be regarded as the pollutants of the 21 st century.

Many studies have already been conducted, but it is still necessary to improve the knowledge of the NPs behaviour and their interactions with various environmental elements. The higher surface energy of NPs, in comparison with metals in macroscale, results in the higher reactivity. On the one hand, NPs can bind with clay minerals, iron oxides and humic substances contained in the environment due to their strong surface charge. On the other hand, they can behave as sorbents of contaminants present in the environment. Their small size improves their mobility in the environment and their penetration into the tissues and organs of aquatic organisms. It is considered appropriate to know and follow the life cycle of NMs because the reactivity of NPs depends on it. The presence of NPs in the environment is not a common problem yet because nanotechnology is a relatively new field of science and technology. Nevertheless, it is certain that the interest in NMs and NPs will gradually grow in time and due to the technology development.

\section{Acknowledgments}

The review presented in this paper is an introduction to the project no. UMO-2012/07/B/ST8/03753, financed by the National Science Centre, Poland, in years 2013-2016. The authors would like to express their sincere thanks to ProofreadingServices.com for the professional and reliable proofreading of this paper.

\section{References}

Adams, L.K., Lyon, D.Y. \& Alvarez, P.J.J. (2006). Comparative eco-toxicity of nanoscale $\mathrm{TiO}_{2}, \mathrm{SiO}_{2}$, and $\mathrm{ZnO}$ water suspensions, Water Research, 40, 3527-3532.

Adeleye, A.S., Keller, A.A., Miller, R.J. \& Lenihan, H.S. (2013). Persistence of commercial nanoscaled zero-valent iron (nZVI) and by-products, Journal of Nanoparticle Research, 15, pp. 1-18.

Aruoja, V., Dubourguier, H.C., Kasemets, K. \& Kahru, A. (2009). Toxicity of nanoparticles of $\mathrm{CuO}, \mathrm{ZnO}$ and $\mathrm{TiO}_{2}$ to microalgae Pseudokirchneriella subcapitata, Science of the Total Environment, 407, pp. 1461-1468.

Babaizadeh, H. \& Hassan, M. (2013). Life cycle assessment of nano-sized titanium dioxide coating on residential windows, Construction and Building Materials, 40, pp. 314-321.

Bae, E., Park, H.J., Yoon, J., Kim, Y., Choi, K. \& Yi, J. (2011). Bacterial uptake of silver nanoparticles in the presence of humic acid and $\mathrm{AgNO}_{3}$, Korean Journal of Chemical Engineering, 28, pp. 267-271.

Balasubramanian, S.K., Yang, L., Yung, L.Y.L., Ong, C.N., Ong, W.Y. \& Yu, L.E. (2010). Characterization, purification, and stability of gold nanoparticles, Biomaterials, 31, pp. 9023-9030.

Becker, H., Herzberg, F., Schulte, A. \& Kolossa-Gehringa, M. (2011). The carcinogenic potential of nanomaterials, their release from products and options for regulating them, International Journal of Hygiene and Environmental Health, 214, pp. 231-238. 
Ben-Moshe, T., Dror, I. \& Berkowitz, B. (2010). Transport of metal oxide nanoparticles in saturated porous media, Chemosphere, 81 , pp. 387-393

Benn, T.M. \& Wasterhoff, P. (2008). Nanoparticle Silver Released into water from commercially available sock fabrics, Environmental Science and Technology, 42, pp. 4133-4139.

Bianchini, A., Rouleau, C. \& Wood, C.M. (2005). Silver accumulation in Daphnia magna in the presence of reactive sulphide, Aquatic Toxicology, 72, pp. 339-349.

Bina, B., Amin, M., Rashidi, A. \& Pourzamani, H. (2012). Benzene and toluene removal by carbon nanotubes from aqueous solution, Archives of Environmental Protection, 38, 1, pp. 3-25.

Blaser, S.A., Scheringer, M., MacLeod, M. \& Hungerbuhler, K. (2008). Estimation of cumulative aquatic exposure and risk due to silver: Contribution of nano-functionalized plastics and textiles, Science of the Total Environment, 390, pp. 396-409.

Blinova, I., Ivask, A., Heinlaan, M., Mortimer, M. \& Kahru, A. (2010). Ecotoxicity of nanoparticles of $\mathrm{CuO}$ and $\mathrm{ZnO}$ in natural water, Environmental Pollution, 158, pp. 41-47.

Blinova, I., Niskanen, J., Kajankari, P., Kanarbik, L., Käkinen, A., Tenhu, H., Penttinen, O.P. \& Kahru, A. (2013). Toxicity of two types of silver nanoparticles to aquatic crustaceans Daphnia magna and Thamnocephalus platyurus, Environmental Science and Pollution Research, 20, pp. 3456-3463.

Bradley, L.E., Castle, L. \& Chaudhry, Q. (2011). Applications of nanomaterials in food packaging with a consideration of opportunities for developing countries, Trends in Food Science and Technology, 22, pp. 604-610.

Brar, S.K., Verma, M., Tyagi, R.D. \& Surampalli, R.Y. (2010). Engineered nanoparticles in wastewater and wastewater sludge - Evidence and impacts, Waste Management, 30, pp. 504-520.

Braydich-Stolle, L.K., Schaeublin, N.M., Murdock, R.C., Jiang, J., Biswas, P., Schlager, J.J. \& Hussain, A.M. (2009). Crystal structure mediates mode of cell death in $\mathrm{TiO}_{2}$ nanotoxicity, Journal of Nanoparticle Research, 11, pp. 1361-1374.

Brinkmann, T., Sartorius, D. \& Frimmel, F.H. (2003). Photobleaching of humic rich dissolved organic matter, Aquatic Science, 65, pp. $415-424$.

Brullot, W., Reddy, N.K., Wouters, J., Valev, V.K., Goderis, B., Vermant, J. \& Verbiest, T. (2012). Versatile ferrofluids based on polyethylene glycol coated iron oxide nanoparticles, Journal of Magnetism and Magnetic Materials, 324, pp. 1919-1925.

Bystrzejewska-Piotrowska, G., Golimowski, J. \& Urban, P. (2009). Nanoparticles: Their potential toxicity, waste and environmental management, Waste Management, 29, pp. 2587-2595.

Cademartini, L. \& Ozin, G.A. (2011). Concepts of Nanochemistry, Wydawnictwo Naukowe PWN, Warszawa 2011.

Carlos, L., Cipollone, M., Soria, D.B., Moreno, M.S., Ogilby, P.R., García Einschlag, F.S. \& Martire, D.O. (2012). The effect of humic acid binding to magnetite nanoparticles on the photogeneration of reactive oxygen species, Separation and Purification Technology, 91, pp. 23-29.

Chattopadhyay, D.P. \& Patel, B.H. (2010). Effect of nanosized colloidal copper on cotton fabric, Journal of Engineered Fibers and Fabrics, 5, pp. 1-6.

Chen, J., Xiu, Z., Lowry, G.V. \& Alvarez, P.J.J. (2011). Effect of natural organic matter on toxicity and reactivity of nano-scale zero-valent iron, Water Research, 45, pp. 1995-2001.

Cho, K.H., Park, J.E., Osaka, T. \& Park, S.G. (2005). The study of antimicrobial activity and preservative effects of nanosilver ingredient, Electrochimica Acta, 51, pp. 956-960.

Choi, O., Deng, K.K., Kim, N.J., Ross, L., Surampallie, R.Y. \& Hua, Z. (2008). The inhibitory effects of silver nanoparticles, silver ions, and silver chloride colloids on microbial growth, Water Research, 42, pp. 3066-3074.
Cockburn, A., Bradford, R., Buck, N., Constable, A., Edwards, G., Haber, B., Hepburn, P., Howlett, J., Kampers, F., Klein, C., Radomski, M., Stamm, H., Wijnhoven, S. \& Wildemann, T. (2012). Approaches to the safety assessment of engineered nanomaterials (ENM) in food, Food and Chemical Toxicology, 50, pp. 2224-2242.

Das, D., Sureshkumar, M.K., Koley, S., Mithal, N. \& Pillai, C.G.S. (2010). Sorption of uranium on magnetite nanoparticles, Journal of Radioanalytical and Nuclear Chemistry, 285, pp. 447-454.

Das, P., Xenopoulos, A., Williams, C.J., Hoque, M.E. \& Metacalfe, C.D. (2012). Effects of silver nanoparticles on bacterial activity in natural waters, Environmental Toxicology and Chemistry, 31, pp. 122-130.

Delay, M., Dolt, T., Woellhaf, A., Sembritzki, R. \& Frimmel, F.H. (2011). Interactions and stability of silver nanoparticles in the aqueous phase: Influence of natural organic matter (NOM) and ionic strength, Journal of Chromatography A, 1218, pp. 4206-4212.

Diegoli, S., Manciulea, A.L., Begum, S., Jones, I.P., Lead, J.R. \& Preece, J.A. (2008). Interaction between manufactured gold nanoparticles and naturally occurring organic macromolecules, Science of the Total Environment, 402, pp. 51-61.

Ding, X.Z., Zhang, F.M., Wang, H.M., Chen, L.Z. \& Liu, X.H. (2000). Reactive ion beam assisted deposition of a titanium dioxide film on a transparent polyester sheet, Thin Solid Films, 368, pp. 257-260.

Dziennik Ustaw (Dz.U.) (2008) Minister of the Environment Regulation about criteria and assessment methods of groundwater status. No. 143, Pos. 896. (in Polish)

Dziennik Ustaw (Dz.U.) (2011) Minister of the Environment regulation about methods of classification ofthe status ofsurface waters andenvironmental quality standardsfor priority substances. No. 257, Pos. 1545. (in Polish)

Espitia, P.J.P., Soares, N.F.F., dos Reis Coimbra, J.S., de Andrade, N.J., Cruz, R.S. \& Medeiros, E.A.A. (2012). Zinc oxide nanoparticles: synthesis, antimicrobial activity and food packaging applications, Food and Bioprocess Technology, 5, pp. 1447-1464.

Esteban-Cubillo, A., Pecharroma, C., Aguilar, E., Santare, J. \& Moya, J.S. (2009). Antibacterial activity of copper monodispersed nanoparticles into sepiolite, Journal of Material Science, 41, pp. 5208-5212.

Fairbairn, E.A., Keller, A.A., Maedler, L., Zhou, D., Pokhrel, S. \& Cherr, G.N. (2011). Metal oxide nanomaterials in seawater: Linking physicochemical characteristics with biological response in sea urchin development, Journal of Hazardous Materials, 192, pp. $1565-1571$.

Fan, W., Shi Z., Yang, X., Cui, M., Wanga, X., Zhang, D., Liu, H. \& Guo, L. (2012). Bioaccumulation and biomarker responses of cubic and octahedral $\mathrm{Cu}_{2} \mathrm{O}$ micro/nanocrystals in Daphnia magna, Water Research, 46, pp. 5991-5988.

Farkas, J., Christian, P., Urrea, J.A.G., Roos, N., Hassellov, M., Tollefsen, K.E. \& Thomas, K.V. (2010). Effects of silver and gold nanoparticles on rainbow trout (Oncorhynchus mykiss) hepatocytes, Aquatic Toxicology, 96, pp. 44-52.

Farkas, J., Peter, H., Christian, P., Urrea, J.A.G., Hassellov, M., Tuorinierni, J., Gustafsson, S., Olsson, E., Hylland, K. \& Thomas, K.V. (2011). Characterization of the effluent from a nanosilver producing washing machine, Environment International, 37 , pp. 1057-1062.

Farre, M., Sanchi, J. \& Barcelo, D. (2011). Analysis and assessment of the occurrence, the fate and the behavior of nanomaterials in the environment, Trends in Analytical Chemistry, 30, pp. 517-527.

Fernandez-Nieves, A. \& de las Nieves, F.J. (1999). The role of $\mathrm{z}$ potential in the colloidal stability of different $\mathrm{TiO}_{2}$ : electrolyte solution interfaces, Colloids and Surfaces A, 148, pp. 231-243.

Fouqueray, M., Dufils, B., Vollat, B., Chaurand, P., Botta, C., Abacci, K., Labille, J., Rose, J. \& Garric, J. (2012). Effects of aged $\mathrm{TiO}_{2}$ 
nanomaterial from sunscreen on Daphnia magna exposed by dietary route, Environmental Pollution, 163, pp. 55-61.

Fujishima, A., Rao, T.N. \& Tryk, D.A. (2000). Titanium dioxide photocatalysis, Journal of Photochemistry and Photobiology C, 1, pp. 1-21.

Fujishima, A. \& Zhang, X. (2006). Titanium dioxide photocatalysis: present situation and future approaches, Comptes Rendus Chimie, 9 , pp. 750-760.

Gangadharan, D., Harshvardan, K., Gnanasekar, G., Dixit, D., Popat, K.M. \& Anand, P.S. (2010). Polymeric microspheres containing silver nanoparticles as a bactericidal agent for water disinfection, Water Research, 44, pp. 5481-5487.

García, A., Espinosa, R., Delgado, L., Casals, E., González, E., Puntes, V., Barata, C., Font, X. \& Sánchez, A. (2011). Acute toxicity of cerium oxide, titanium oxide and iron oxide nanoparticles using standardized tests, Desalination, 269, pp. 136-141.

Gericke, M. \& Pinches, A. (2006). Microbial production of gold nanoparticles, Gold Bulletin, 39, pp. 22-28.

Glover, C.N. \& Wood, C.M. (2004). Physiological interactions of silver and humic substances in Daphnia magna: effects on reproduction and silver accumulation following an acute silver challenge, Comparative Biochemistry and Physiology C, 139, pp. $273-280$.

Gonzalez, C.M., Hernandez, J., Peralta-Videa, J.R., Botez, C.E., Parsons, J.G. \& Gardea-Torresdey, J.L. (2012). Sorption kinetic study of selenite and selenate onto a high and low pressure aged iron oxide nanomaterial, Journal of Hazardous Materials, 211-212, pp. 138- 145.

Gottschalk, F., Ort, C., Scholz, R.W. \& Nowack, B. (2011). Engineered nanomaterials in rivers - Exposure scenarios for Switzerland at high spatial and temporal resolution, Environmental Pollution, 159, pp. 3439-3445.

Gubbins, E.J., Batty, L.C. \& Lead, J.R. (2011). Phytotoxicity of silver nanoparticles to Lemna minor L, Environmental Pollution, 159, pp. 1551-1559.

Guerard, J.J., Miller, P.L., Trouts, T.D. \& Chin, Y.P. (2009). The role of fulvic acid composition in the photosensitized degradation of aquatic contaminants, Aquatic Sciences, 71, pp. 160-169.

Hebeish, A., El-Naggar, M.E.E., Fouda, M.M.G., Ramadan, M.A., Al-Deyab, S.S. \& El-Rafie, M.H. (2011). Highly effective antibacterial textiles containing green synthesized silver nanoparticles, Carbohydrate Polymers, 86, pp. 936-940.

Heinlaan, M., Ivask, A., Blinova, I., Dubourguier, H.C. \& Kahru, A. (2008). Toxicity of nanosized and bulk $\mathrm{ZnO}, \mathrm{CuO}$ and $\mathrm{TiO}_{2}$ to bacteria Vibrio fischeri and crustaceans Daphnia magna and Thamnocephalus platyurus, Chemosphere, 71, pp. 1308-1316.

Hernández-Sierra, J.F., Ruiz, F., Cruz Pena, D.C., Martínez-Gutiérrez, F., Martinez, A.E., Guillén, A.J.P., Tapia-Pérez, H. \& Castañón, G.M. (2008). The antimicrobial sensitivity of Streptococcus mutans to nanoparticles of silver, zinc oxide, and gold, Nanomedicine \& Nanotechnology, 4, pp. 237-240.

Hoyt, V.W. \& Mason, E. (2008). Nanotechnology Emerging health issues, Journal of Chemical Health \& Safety, 15, pp. 10-15.

Iavicoli, I., Leso, V. \& Bergamaschi, A. (2012). Toxicological effects of titanium dioxide nanoparticles: a review of in vivo studies, Journal of Nanomaterials, 2012, pp. 1-36.

Illes, E. \& Tombacz, E. (2006). The effect of humic acid adsorption on $\mathrm{pH}$-dependent surface charging and aggregation of magnetite nanoparticles, Journal of Colloid and Interface Science, 295, pp. 115-123.

Jadhav, S., Gaikwad, S., Nimse, M. \& Rajbhoj, A. (2011). Copper oxide nanoparticles: synthesis, characterization and their antibacterial activity, Journal of Cluster Science, 22, pp. 121-129.

Jasiorski, M., Leszkiewicz, A., Brzeziński, S., Bugla-Płoskońska, G., Malinowska, G., Borak, B., Karbownik, I., Baszczuk, A., Stręk, W. \& Doroszkiewicz, W. (2009). Textile with silver silica spheres: its antimicrobial activity against Escherichia coli and Staphylococcus aureus, Journal of Sol-Gel Science and Technology, 51, pp. 330-334.

Jegadeesan, G., Al-Abed, S.R., Sundaram, V., Choi, H., Scheckel, K.G. \& Dionysiou, D.D. (2010). Arsenic sorption on $\mathrm{TiO}_{2}$ nanoparticles: Size and crystallinity effects, Water Research, 44, pp. 965-973.

Jiang, X., Tong, M. \& Kim, H. (2012). Influence of natural organic matter on the transport and deposition of zinc oxide nanoparticles in saturated porous media, Journal of Colloid Interface Science, 386, pp. 34-43.

Jiang, X., Tong, M., Lu, R. \& Kim, H. (2012a). Transport and deposition of $\mathrm{ZnO}$ nanoparticles in saturated porous media, Colloid Surface A, 401, pp. 29-37.

Jiang, X., Tong, M., Li, H. \& Yang, K. (2010). Deposition kinetics of zinc oxide nanoparticles on natural organic matter coated silica surfaces, Journal of Colloid Interface Science, 350, pp. 427-434.

Jo, H.J., Choi, J.W., Lee, S.H. \& Hong, S.W. (2012). Acute toxicity of $\mathrm{Ag}$ and $\mathrm{CuO}$ nanoparticle suspensions against Daphnia magna: The importance of their dissolved fraction varying with preparation methods, Journal of Hazardous Materials, 227-228, pp. 301-308.

Jones, E.H. \& Su, C. (2012). Fate and transport of elemental copper $\left(\mathrm{Cu}^{0}\right)$ nanoparticles through saturated porous media in the presence of organic materials, Water Research, 46, pp. 2445-2456.

Juárez-Moreno, K., Pestryakov, A. \& Petranovskii, V. (2014). Engineering of supported nanomaterials, Procedia Chemistry, 10, pp. $25-30$.

Kadar, E., Simmance, F., Martin, O., Voulvoulis, N., Widdicombe, S., Mitov, S., Lead, J.R. \& Readman, J.W. (2010). The influence of engineered $\mathrm{Fe}_{2} \mathrm{O}_{3}$ nanoparticles and soluble $\left(\mathrm{FeCl}_{3}\right)$ iron on the developmental toxicity caused by $\mathrm{CO}_{2}$-induced seawater acidification, Environmental Pollution, 158 , pp. 3490-3497.

Kamisli, F. \& Turan, C. (2005). A study on usability of magnesium oxide with titanium dioxide in PVC door and window profiles, Journal of Materials Processing Technology, 159, pp. 40-47.

Kelsall, R.W., Hamley, I.W \& Geoghegan, M. (2009). Nanoscale Science and Technology, Wydawnictwo Naukowe PWN, Warszawa 2009.

Kim, E., Kim, S.H. \& Kim, H.C. (2011). Growth inhibition of aquatic plant caused by silver and titanium oxide nanoparticles, Toxicology and Environmental Health Sciences, 3, pp. 1-6.

Kim, S.W., Nam, S.H. \& An, Y.J. (2012). Interaction of silver nanoparticles with biological surfaces of Caenorhabditis elegans, Ecotoxicology and Environmental Safety, 77, pp. 64-70.

Kim, B., Park, C.S., Murayama, M. \& Hochella, M.F. (2010). Discovery and characterization of silver sulfide nanoparticles in final sewage sludge products, Environmental Science and Technology, 44, pp. 7509-7514.

Kim, K.J., Sung, W.S., Suh, B.K., Moon, S.K., Choi, J.S., Kim, J.G. \& Lee, D.G. (2009). Antifungal activity and mode of action of silver nanoparticles on Candida albicans, Biometals, 22, pp. 235-242.

Kunzmann, A., Andersson, B., Thurnherr, T., Krug, H., Scheynius, A. \& Fadeel, B. (2011). Toxicology of engineered nanomaterials: Focus on biocompatibility, biodistribution and biodegradation, Biochimica et Biophysica Acta, 1810, pp. 361-373.

Kurzydłowski, K. \& Lewandowska, M. (2011). Nanomateriały inżynierskie, konstrukcyjne i funkcjonalne, Wydawnictwo PWN, Warszawa 2011. (in Polish)

Landsiedel, R., Fabian, E., Ma-Hock, L., Wohlleben, W., Wiench, K., Oesch, F. \& Van Ravenzwaay, B. (2012). Toxico-/biokinetics of nanomaterials, Archives of Toxicology, 86, pp. 1021-1060. 
Lapresta-Fernandez, A., Fernandez, A. \& Blasco, J. (2012). Nanoecotoxicity effects of engineered silver and gold nanoparticles in aquatic organisms, Trends in Analytical Chemistry, 32, pp. 40-59.

Larue, C., Khodja, H., Herlin-Boime, N., Brisset, F., Flank, A.M., Fayard, B., Chaillou, S. \& Carrière, M. (2011). Investigation of titanium dioxide nanoparticles toxicity and uptake by plants. Journal of Physics: Conference Series 304. Nanosafe2010: International Conference on Safe Production and Use of Nanomaterials IOP Publishing, pp. 1-7.

Lee, H.J., Yeo, S.Y. \& Jeong, S.H. (2003). Antibacterial effect of nanosized silver colloidal solution on textile fabrics, Journal of Materials Science, 38, pp. 2199-2204.

Lee, S., Lee, J., Kim, K., Sim, S.J., Gu, M.B., Yi, J. \& Lee, J. (2009). Eco-toxicity of commercial silver nanopowders to bacterial and yeast strains, Biotechnology and Bioprocess Engineering, 14, pp. 490-495.

Lee, B.T. \& Ranville, J.F. (2012). The effect of hardness on the stability of citrate-stabilized gold nanoparticles and their uptake by Daphnia magna, Journal of Hazardous Materials, 213-214, pp. 434-439.

Lewicka, Z.A., Benedetto, A.F., Benoit, D.N., Yu, W.W., Fortner, J.D. \& Colvin, V.L. (2011). The structure, composition, and dimensions of $\mathrm{TiO}_{2}$ and $\mathrm{ZnO}$ nanomaterials in commercial sunscreens, Journal of Nanoparticles Research, 13, pp. 3607-3617.

Liang, Z., Das, A. \& Hu, Z. (2010). Bacterial response to a shock load of nanosilver in an activated sludge treatment system, Water Research, 44, pp. 5432-5438.

Lin, D., Ji, J., Long, Z., Yang, K. \& Wu, F. (2012). The influence of dissolved and surface-bound humic acid on the toxicity of $\mathrm{TiO}_{2}$ nanoparticles to Chlorella sp., Water Research, 46, pp. 4477-4487.

Liu, Y., Liu, C.-Y., Chen, L. \& Zhang, Z. (2003). Adsorption of cations onto the surfaces of silver nanoparticles, Journal of Colloid Interface Science, 257, pp. 188-194.

Liu, H., Yang, D., Yang, H., Zhang, H., Zhang, W., Fan, Y., Lin, Z., Tian, L., Lin, B., Yan, J. \& Xi, Z. (2013). Comparative study of respiratory tract immune toxicity induced by three sterilisation nanoparticles: Silver, zinc oxide and titanium dioxide, Journal of Hazardous Materials, 248-249, pp. 478-486.

Lok, C.N., Ho, C.M., Chen, R., He, Q.Y., Yu, W.Y., Sun, H., Tam, P.K.H., Chiu, J.F. \& Che, C.M. (2007). Silver nanoparticles: partial oxidation and antibacterial activities, Journal of Biological Inorganic Chemistry, 12, pp. 527-534.

Łebkowska, M. \& Załęska-Radziwiłł, M. (2011). Nanoparticles - mode of occurence and ecotoxicity, Ochrona Środowiska, 33, pp. 23-26.

Makles, Z. (2005). Nanomateriały - nowe możliwości, nowe zagrożenia, Bezpieczeństwo Pracy 2, pp. 2-4. (in Polish)

Maness, P.C., Smolinski, S., Blake, D.M., Huang, Z., Wolfrum, E. \& Jacoby, W.A. (1999). Bactericidal activity of photocatalytic $\mathrm{TiO}_{2} \mathrm{r}$ : toward an understanding of its killing mechanism, Applied and Environmental Microbiology, 65, pp. 4094-4098.

Marambio-Jones, C. \& Hoek, E.M.V. (2010). A review of the antibacterial effects of silver nanomaterials and potential implications for human health and the environment, Journal of Nanoparticles Research, 12, pp. 1531-1551.

Maynard, A.D. (2006). Nanotechnology: assessing the risk, Nanotoday, 1, pp. 22-33.

McLaughlin, J. \& Bokzongo, J.C. (2012). Effects of natural water chemistry on nanosilver behavior and toxicity to Ceriodaphnia dubia and Pseudokirchneriella subcapitata, Environmental Toxicology and Chemistry, 31, pp. 168-175.

Meng, H., Chen, Z., Xing, G., Yuan, H., Chen, Ch., Zhao, F., Zhang, C. \& Zhao, Y. (2007). Ultrahigh reactivity provokes nanotoxicity: Explanation of oral toxicity of nano-copper particles, Toxicology Letters, 175, pp. 102-110.
Meyer, D.E., Curruan, M.A. \& Gonzalez, M. (2011). An examination of silver nanoparticles in sock using screening-level life cycle assessment, Journal of Nanoparticles Research, 13, pp. 147-156.

Mills, A., Hills, G., Bhopal, S., Parkin, I.P. \& O’Neill, S.A. (2003). Thick titanium dioxide films for semiconductors photocatalysis, Journal of Photochemistry and Photobiology A, 160, pp. 185-194.

Mohmood, I., Lopes, C.B., Lopes, I., Ahmad, I., Duarte, A.C. \& Pereira, E. (2013). Nanoscale materials and their use in water contaminants removal - a review, Environmental Science and Pollution Research, 20, pp. 1239-1260.

Narayanan, P.M., Wilson, W.S., Abraham, A.T. \& Sevanan, M. (2012). Synthesis, characterization, and antimicrobial activity of zinc oxide nanoparticles against human pathogens, Journal of Bionanoscience, 2, pp. 329-335.

Nor, N.M., Razak, K.A., Tan, S.C. \& Noordin, R. (2012). Properties of surface functionalized iron oxide nanoparticles (ferrofluid) conjugated antibody for lateral flow immunoassay application, Journal of Alloys and Compounds, 538, pp. 100-106.

Nowack, B., Heuberger, M. \& Geranio, L. (2009). The behavior of silver nano-textiles during washing, Environmental Science \& Technology, 43 (21), pp. 8113-8118.

Olushola, S.A., Olalekan, S.F., Folahan A.A., Bhekumusa J.X., Olatunbosun S.A., Leslie F.P. (2015). Coal fly ash supported $\mathrm{nZnO}$ for the sorption of triphenyltin chloride, Archives of Environmental Protection, 41, 1, pp. 59-71.

Pawlett, M., Ritz, K., Dorey, R.A., Rocks, S., Ramsden, J. \& Harris, J.A. (2013). The impact of zero-valent iron nanoparticles upon soil microbial communities is context dependent, Environmental Science and Pollution Research, 20, pp. 1041-1049.

Pedahzur, R., Shuval, H.I. \& Ulitzur, S. (1997). Silver and hydrogen peroxideas potential drinking water disinfectants: their bactericidal effects and possible modes of action, Water Science and Technology, 35, pp. 87-93.

Peralta-Videa, J.R., Zhao, L., Lopez-Moreno, M.L., De La Rosad, G., Hong, J. \& Gardea-Torresdey, G.J. (2011). Nanomaterials and the environment: A review for the biennium 2008-2010, Journal of Hazardous Materials, 186, pp. 1-15.

Petosa, A.R., Brennan, S.J., Rajput, F. \& Tufenkji, N. (2012). Transport of two metal oxide nanoparticles in saturated granular porous media: Role of water chemistry and particle coating, Water Research, 46, pp. 1273-1285.

Pradhan, A., Seena, S., Pascoal, C. \& Cassio, F. (2012). Copper oxide nanoparticles can induce toxicity to the freshwater shredder Allogamus ligonifer, Chemosphere, 89, pp. 1142-1150.

Radziga, M.A., Nadtochenkoc, V.A., Koksharovaa, O.A., Kiwi, J., Lipasovaa, V.A. \& Khmela, I.A. (2013). Antibacterial effects of silver nanoparticles on gram-negative bacteria: Influence on the growth and biofilms formation, mechanisms of action, Colloid Surface B, 102, pp. 300-306.

Raffi, M., Mehrwan, S., Bhatti, M.T., Akhter, J.I., Hameed, A., Yawar, W. \& Hasan, M. (2010). Investigations into the antibacterial behavior of copper nanoparticles against Escherichia coli, Annals of Microbiology, 60, pp. 75-80.

Ramani, M., Ponnusamy, S. \& Muthamizhchelvan, C. (2012). From zinc oxide nanoparticles to microflowers: A study of growth kinetics and biocidal activity, Materials Science and Engineering C, 32, pp. 2381-2389.

Ramyadevi, J., Jeyasubramanian, A., Marikani, A., Rajakumar, G. \& Rahuman, A.A. (2012). Synthesis and antimicrobial activity of copper nanoparticles, Materials Letters, 71, pp. 114-116.

Ratte, H.T. (1999). Bioaccumulation and toxicity of silver compounds: A review, Environmental Toxicology and Chemistry, 18, pp. 89-108.

Ren, G., Hu, D., Cheng, E.W.C., Vargas-Reusc, M.A., Reipd, P. \& Allaker, R.P. (2009). Characterisation of copper oxide nanoparticles for antimicrobial applications, International Journal of Antimicrobial Agents, 33, pp. 587-590. 
Revati, A.K. \& Pandey, B.D. (2011). Microbial synthesis of iron-based nanomaterials - A review, Bulletin of Materials Science, 34, pp. 191-198.

Rincon, A.G. \& Pulgarin, C. (2004). Bactericidal action of illuminated $\mathrm{TiO}_{2}$ on pure Escherichia coli and natural bacterial consortia: post-irradiation events in the dark and assessment of the effective disinfection time, Applied Catalysis B: Environmental, 49, pp. 99-112.

Rispoli, F., Angelov, A., Badia, D., Kumar, A., Seal, S. \& Shah, V. (2010). Understanding the toxicity of aggregated zero valent copper nanoparticles against Escherichia coli, Journal of Hazardous Materials, 180, pp. 212-216.

Rostek, A., Mahl, D. \& Epple, M. (2011). Chemical composition of surface-functionalized gold nanoparticles, Journal of Nanoparticles Research, 13, pp. 4809-4814.

Sagee, O., Dror, I. \& Berkowitz, B. (2012). Transport of silver nanoparticles (AgNPs) in soil, Chemosphere, 88, pp. 670-675.

Schwegmann, H., Feitz, A.J. \& Frimmel, F.H. (2010). Influence of the zeta potential on the sorption and toxicity of iron oxide nanoparticles on S. cerevisiae and E. coli, Journal of Colloid Interface Science, 347, pp. 43-48.

Sheela, T., Nayaka, A., Viswanatha, R., Basavanna, S. \& Venkatescha, T.G. (2012). Kinetics and thermodynamics studies on the adsorption of $\mathrm{Zn}(\mathrm{II}), \mathrm{Cd}(\mathrm{II})$ and $\mathrm{Hg}(\mathrm{II})$ from aqueous solution using zinc oxide nanoparticles, Powder Technology, 217, pp. 163-170.

Sheng, Z. \& Liu, Y. (2011). Effects of silver nanoparticles on wastewater biofilms, Water Research, 45, pp. 6039-6050.

Shipley, H.J., Engates, K.E. \& Guettner, A.M. (2011). Study of iron oxide nanoparticles in soil for remediationof arsenic, Journal of Nanoparticles Research, 13, pp. 2387-2397.

Sinha, R., Karan, R., Sinha, A. \& Khare, S.K. (2011). Interaction and nanotoxic effect of $\mathrm{ZnO}$ and $\mathrm{Ag}$ nanoparticles on mesophilic and halophilic bacterial cells, Bioresource Technology, 102, pp. 1516-1520.

Skocaj, M., Filipic, M., Petkovic, J. \& Novak, S. (2011). Titanium dioxide in our everyday life; is it safe? Radiology and Oncology, 45 , pp. $227-247$

Sondi, I. \& Salopek-Sondi, B. (2004). Silver nanoparticles as antimicrobial agent: a case study on E. coli as a model for Gram-negative bacteria, Journal of Colloid Interface Science, 275, pp. 177-182.

Strigula, N., Vaccaria, L., Galduna, C., Waznea, M., Liua, X., Christodoulatosa, C. \& Jasinkiewicz, K. (2009). Acute toxicity of boron, titanium dioxide, and aluminum nanoparticles to Daphnia magna and Vibrio fischeri, Desalination, 248, pp. 771-782.

Tan, X., Wang, X., Chen, C. \& Sun, A. (2007). Effect of soil humic and fulvic acids, $\mathrm{pH}$ and ionic strength on Th(IV) sorption to $\mathrm{TiO} 2$ nanoparticles, Applied Radiation and Isotopes, 65, pp. 375-381.

Tazawa, M., Oksada, M., Yoshimura, K. \& Ikezawa, S. (2004). Photocatalytic heat mirror with a thick titanium dioxide layer, Solar Energy Material and Solar Cells, 84, pp. 159-170.

Tedesco, S., Doyle, H., Blasco, J., Redmond, G. \& Sheehan, D. (2010). Oxidative stress and toxicity of gold nanoparticles in Mytilus edulis, Aquatic Toxicology, 100, pp. 178-186.
Uheida, A., Iglesias, M., Fontas, C., Hidalgo, M., Salvado, V., Zhang, Y. \& Muhammed, M. (2006). Sorption of palladium(II), rhodium(III), and platinum(IV) on $\mathrm{Fe}_{3} \mathrm{O}_{4}$ nanoparticles, Journal of Colloid Interface Science, 301, pp. 402-408.

US EPA (2002) National Recommended Water Quality Criteria, EPA-822-R02-047.

US EPA (2009) National Primary Drinking Water Regulation, EPA-816-F-09-0004.

Walser, T., Demon, E., Lang, D.J. \& Hellweg, S. (2011). Prospective environmental life cycle assessment of nanosilver T-shirts, Environmental Science and Technology, 45, pp. 4570-4578.

Wang, C., Wang, L., Wang, Y., Liang, Y. \& Zhang, J. (2012). Toxicity effects of four typical nanomaterials on the growth of Escherichia coli, Bacillus subtilis and Agrobacterium tumefaciens, Environmental Earth Sciences, 65, pp. 1643-1649.

Wilson, M.R., Foucaud, L., Barlow, P.G., Hutchison, G.R., Sales, J., Simpson, R.J. \& Stone, V. (2007). Nanoparticle interactions with zinc and iron: Implications for toxicology and inflammation, Toxicology and Appllied Pharmacology, 225, pp. 80-89.

Wzorek, Z. \& Konopka, M. (2007). Nanosilver-a new bactericidal agent, Czasopismo Techniczne Chemia, 104, pp. 175-181. (in Polish)

Yazdanshenas, M.E. \& Shateri-Khalilabad, M. (2012). The effect of alkali pre-treatment on formation and adsorption of silver nanoparticles on cotton surface, Fibers and Polymers, 13, pp. 1170-1178.

Yoon, K.Y., Byeon, J.H., Park, J.H. \& Hwang, J. (2007). Susceptibility constants of Escherichia coli and Bacillus subtilis to silver and copper nanoparticles, Science of the Total Environment, 373, pp. 572-575.

Zhang, L., Liu, N., Yang, L. \& Lin, Q. (2009). Sorption behavior of nano$-\mathrm{TiO}_{2}$ for the removal of selenium ions from aqueous solution, Journal of Hazardous Materials, 170, pp. 1197-1203.

Zhang, Y., Chen, Y., Wasterhoff, P., Hristovski, K. \& Crittenden, J.C. (2009). Impact of natural organic matter and divalent cations on the stability of aqueous nanoparticles, Water Research, 43, pp. 4249-4257.

Zhang, F., Wu, X., Chen, Y. \& Lin, H. (2009a). Application of silver nanoparticles to cotton fabric as an antibacterial textile finish, Fibers and Polymers, 10, pp. 496-501.

Zhang, L., Ting Huang, T., Liu, N., Liu, X. \& Li, H. (2009b). Sorption of thallium (III) ions from aqueous solutions using titanium dioxide nanoparticles, Microchimica Acta, 165, pp. 73-78.

Zhang, X.Q., Xu, X., Bertrand, N., Pridgen, E., Swami, A. \& Farokhzad, O.C. (2012). Interactions of nanomaterials and biological systems: Implications to personalized nanomedicine, Advanced Drug Delivery Reviews, 64, pp. 1363-1384.

Zhang, L., Jiang, Y., Ding, Y., Povey, M. \& York, D. (2007). Investigation into the antibacterial behaviour of suspensions of $\mathrm{ZnO}$ nanoparticles ( $\mathrm{ZnO}$ nanofluids), Journal of Nanoparticles Research, 9, pp. 479-489.

Zhou, D. \& Keller, A.A. (2010). Role of morphology in the aggregation kinetics of $\mathrm{ZnO}$ nanoparticles, Water Research, 44, pp. 2948-2956.

Zhu, X., Zhu, L., Chen, Y. \& Tian, S. (2009). Acute toxicities of six manufactured nanomaterial suspensions to Daphnia magna, Journal of Nanoparticles Research, 11, pp. 67-75.

\section{Nanomateriały nieorganiczne w środowisku wodnym: zachowanie, toksyczność i interakcje z innymi elementami środowiska}

Streszczenie: Celem pracy jest charakterystyka, toksyczność oraz zachowanie w środowisku nanomateriałów (takich jak srebro, miedź, złoto, tlenek cynku, dwutlenek tytanu, tlenki żelaza), które występują najczęściej w produktach konsumenckich. Dodatkowo, nanomateriały określane są jako nowe zanieczyszczenia środowiska wodnego XXI wieku. $\mathrm{Z}$ jednej strony mogą być adsorbowane przez elementy środowiska wodnego (tj. minerały ilaste, kwasy fulwowe 
i huminowe), z drugiej zaś to one stają się centrami adsorpcyjnymi zanieczyszczeń środowiskowych (tj. jony metali ciężkich, związki organiczne). Najbardziej rozpowszechnione nanosrebro jest uwalniane z produktów dostępnych na rynku do środowiska wodnego, co powoduje zagrożenie dla organizmów wodnych z powodu wysokiej toksyczności srebra. Nanomiedź natomiast jest uważana za jeden z najsilniejszych środków antybakteryjnych i przeciwgrzybicznych, nawet w porównaniu do nanosrebra. Nanocząstki charakteryzują się niewielkimi rozmiarami co pozwala im na wnikanie do żywych komórek, a także wysoką reaktywnością dzięki czemu mogą zakłócać metabolizm komórek oraz cykle geochemiczne bakterii. Nanomateriały ulegają aglomeracji, wiążą się zarówno z jonami jak i związkami organicznymi, mogą również zostać zatrzymane na powierzchni osadów a ich interakcje uzależnione są od warunków środowiska (pH, siła jonowa, temperatura, oraz obecność innych związków chemicznych). Niestety ich zachowanie w środowisku nie jest do końca poznane. Dlatego konieczne są badania nad zachowaniem się nanomateriałów w środowisku wodnym, ich toksyczności i interakcji z elementami środowiska wodnego. Zagrażając organizmom wodnym mogą one również negatywnie wpływać na zdrowie i życie ludzkie. Zasadne wydaje się zatem poznanie regulacji i praw które pozwolą na określenie dopuszczalnych stężeń nanocząstek w środowisku. 